Article

\title{
Strip Clear-Cutting Application and Logging Typologies for Renaturalization of Pine Afforestation-A Case Study
}

\author{
Rodolfo Picchio ${ }^{1, *}$ (D) , Roberto Mercurio ${ }^{2}$, Rachele Venanzi ${ }^{1}$, Loretta Gratani ${ }^{3}$, \\ Tommaso Giallonardo ${ }^{4}$, Angela Lo Monaco ${ }^{1}$ (1) and Anna Rita Frattaroli ${ }^{4}$ \\ 1 Department of Agriculture and Forest Sciences (DAFNE), Tuscia University, Via S. Camillo de Lellis, \\ 01100 Viterbo, Italy; venanzi@unitus.it (R.V.); lomonaco@unitus.it (A.L.M.) \\ 2 Department of Agraria, University of Reggio Calabria, Salita Melissari, 89124 Reggio Calabria, Italy; \\ rmercurio@unirc.it or rmercurio@inwind.it \\ 3 Department of Environmental Biology, Università degli Studi di Roma La Sapienza, Piazzale Aldo Moro, 5, \\ 00185 Rome, Italy; loretta.gratani@uniroma1.it \\ 4 Department of Life, Health and Environmental Sciences, Università degli Studi dell'Aquila, \\ Piazzale Salvatore Tommasi 1, Blocco 11, Coppito, 67100 L'Aquila, Italy; tommy.giallonardo@libero.it (T.G.); \\ annarita.frattaroli@univaq.it (A.R.F.) \\ * Correspondence: r.picchio@unitus.it; Tel.: +39-076-135-7400
}

Received: 18 April 2018; Accepted: 8 June 2018; Published: 19 June 2018

\begin{abstract}
Renaturalization treatment in black pine afforestation is an important topic that should be considered. There is a need to favor the evolution of artificial pine forests toward natural forest systems. Overall, this study focused on pine forests, and suggests one typology of clear-cutting (dismantling cutting) on strips, which is associated with different extraction management techniques. Some ecological and environmental aspects associated with renaturalization treatments that have been applied by different mechanizations in black pine afforestation have been highlighted, as well as how renaturalization and the active ecological management of these stands could affect soil and vegetation. The main objectives of this research were to: (1) analyze the impact of silvicultural treatment and logging activities on forest soil, and (2) assess tree regeneration and floristic biodiversity in an ecological management system, in terms of both quantity and quality characteristics. These analyses were planned to obtain an overview of the environmental impact related to a multifunctional approach to the forest management of black pine afforestation. Essentially, the answers to the main research questions are: (1) less invasive extraction systems seem to use a cable yarder and forest winch; (2) a clear soil recovery trend with good capabilities is visible, in particular for the two extraction systems by cable; however, over a three-year period, only a partial but substantial recovery has been shown; (3) in general, silvicultural treatment showed qualitative and quantitative improvement in terms of tree regeneration; in particular, the extraction systems by forest winch and cable yarder showed better results; (4) silvicultural treatment seems not to have led to improvement at the level of the herbaceous and shrubby layers; however, clear differences are shown among the different harvesting systems. Significant recovery after use of the cable yarder was observed.
\end{abstract}

Keywords: dismantling cutting; horse skidding; winch skidding; cable yarder; tree regeneration; soil recovery

\section{Introduction}

Among the different coniferous species, black pine (Pinus nigra Arnold) has been successfully used in Italy since the beginning of last century for afforestation, as well as the recolonization of pastures 
and degraded environments due to its favorable frugal characteristics [1,2]. Black pine is appropriate for afforestation in shallow soils with severe climatic conditions such as prolonged summer drought, due to its root system extension [1]. In 2005, Pinus nigra forests covered an area of approximately 240,000 ha (about 3\% of the forested area in Italy) [3]. This afforestation provides soil protection and the restarting of dynamic and evolutionary processes of vegetation.

Tonon et al. [4] highlighted that black pine afforestation modified microclimate and soil conditions, making them suitable for more discerning species. Nevertheless, today many of these afforested areas are in a poor physical and biological state with no dynamic processes. This is due to the combination of several factors (i.e., the inadequate treatment and biotic and environmental adversity). Thus, these areas require urgent silvicultural action in the form of renaturalization [5,6] to ensure the permanence of land cover, with the gradual replacement of pine with late successional tree species that are typical of more mature stages of evolution (native broadleaves). Furthermore, the woody material that was required as a source of renewable energy opens up interesting prospects for the use of biomass obtainable by the renaturalization of these types of forests.

The application of silvicultural treatments has important effects on all of the ecological aspects [7-9]. Soil characteristics and tree functioning may be affected by harvesting due to the modified input of light (quality and quantity), temperature, and water availability. Moreover, it is important to highlight that logging activities, with machine and load traffic, may cause soil compaction, soil horizon mixing, and topsoil removal [10]. Compaction reduces soil porosity and the connectivity of pores, thus increasing soil density and shear strength $[9,11,12]$. Thus, soil degradation could reduce tree growth [13], and carbon dioxide efflux from the soil may change significantly [14]. After a renaturalization treatment, the restocking of the stand is left to two main natural regeneration processes: through seedlings (gamic) and sprouts (agamic). Due to the high sprouting potential of some broadleaves growing under the canopy cover of the pine forest, the dynamics of recruiting new individuals to existing stands has largely been overlooked [15]. This aspect will be of particular interest for these new forests that are composed of a mosaic of artificial and natural stands.

Biodiversity conservation has long been a goal of European conservation policy [16,17]. However, despite more than $25 \%$ of European land having been given some level of protection for conservation, biodiversity continues to decline [18]. One factor contributing to this decline may be unsuitable management practices in protected areas, or, more specifically, an insufficient application of evidence-based conservation recommendations [18,19]; for example, a lack of diversity of management systems with a total abandonment of traditional systems, without considering the possibility of improving them. Biodiversity monitoring is essential in order to support management decisions in maintaining multiple forest ecosystem functions [20]. A better understanding of the roles of the components of biological diversity that support the provision of multiple forest ecosystem services is necessary $[21,22]$.

Logging systems may differ depending on silvicultural management and the final products. The technical and economic utilization of forests depend on various factors concerning terrain conditions, transportation networks, and harvesting technologies, as well as silvicultural treatment and forest operation systems $[23,24]$. Although in recent times there have been significant innovations in forest operations $[8,25]$ in terms of both technology and methodology, logging activities in Italy are still developed by traditional methods, i.e., motor-manual felling with chainsaws and the use of mules and/or agricultural tractors for extraction [25-27].

Actually, studies focusing on the effects of silvicultural treatment and utilization on soil and plant biodiversity are rare, or are overly guided by extreme currents of thought. Without some clear effects and recovery times, it is very difficult to respect the concept of sustainability. Also for these reasons, companies are seldom required to take into account the impact of their operations on the land and on forest sustainability, or, rather, to consider the real application of sustainable forest management as suggested by Forest Europe. 
For these reasons as well as the fundamental purposes of renaturalization, it is important to know and assess the possible impacts on the soil and biodiversity of silvicultural treatments and logging operations, considering that one of the most important problems of the forest sector is to minimize ground damage caused by forest operations [28] and biodiversity loss. In general, the effects of harvesting include changes in vegetation, nutrient availability, and soil microclimate and structure, as well as litter quantity and quality [28]. In particular, forest operations, such as forwarding and skidding, have a high potential for soil compaction [29-31]. However, adequately managed forest ecosystems are claimed to be highly resilient in the long term [32].

The modern silvicultural approaches lead to aggregated retention, which is the practice of leaving unlogged patches within logged areas, and is a form of retention forestry that has gained increasing use globally as an alternative to clear-cut logging [33-35]. In contrast to clear-cutting, retention forestry maintains habitats for species affiliated with a closed forest-thus mitigating the negative effects of timber harvest—while also providing a habitat for early seral species $[36,37]$. These approaches are characterized by a set of fundamental principles, including an avoidance of clear-cutting, an emphasis on structural diversity and small-scale variability, the deployment of mixed species with natural regeneration, and an avoidance of intensive site-preparation methods [38]. However, although these modern approaches find real justification in the management of "natural" forests, they have some complications in the renaturalization practices or management of forest monospecific plantations. In these cases, which are similar to problems with new silvicultural approaches [38], a suite of ecological, economic, logistical, informational, cultural, and historical constraints currently hinder the wider adoption of alternative silvicultural practices. Individual contexts display their own unique combinations and the relative significance of these constraints, and accordingly, targeted efforts, such as regulations and incentives, may help overcome specific challenges. In a broader context, the possibility of clear-cutting treatments on adequate surfaces and with proper methodologies might provide an additional flexibility and facilitate renaturalization within a broader set of ecological circumstances.

In order to improve silvicultural management and logging methods, better knowledge of the long-term impact of forest operations is needed [26,39]. Reducing the negative effects of felling and extraction is one of the main goals of sustainable forest management [40-42].

The main objectives of this research were to (1) analyze the impact of silvicultural treatment and logging activities on forest soil, and (2) assess tree regeneration and floristic biodiversity in an ecological management system, in terms of both quantity and quality characteristics.

To analyze the impact on soil and short-term recovery in particular, in addition to physical and chemical analyses of soil (i.e., pH, organic matter, bulk density, penetration and shear resistance) [30], an innovative arthropod-based Soil Biological Quality index, QBS-ar [43,44], was used. This is a valuable tool in ecosystem restoration programs for monitoring the development of soil functions and biodiversity, and preventing the negative effects of soil compaction that result from logging activities.

Moreover, other ecological and environmental aspects associated with renaturalization treatments were evaluated in black pine afforestation in relation to tree regeneration characteristics and vegetation dynamics. In particular, the most important points in investigating the renaturalization and active ecological management of these Pinus nigra forests were as follows:

- Three mainly different logging methodologies and their immediate impact on some soil features

- Possible recovery time of the impact on soil features over a range of three years

- The effect of silvicultural treatment and logging activities on natural tree regeneration

- First analysis of silvicultural treatment and logging activities on plant structure and functioning

These analyses were planned so as to obtain an overview of the environmental impacts related to a multifunctional approach to the forest management of black pine afforestation. 


\section{Materials and Methods}

\subsection{Study Site}

The studied areas are located near Passo delle Capannelle Municipality of Pizzoli (AQ $42^{\circ} 26^{\prime} 49$ N, $13^{\circ} 20^{\prime} 14 \mathrm{E}$ ) (Figure 1). Abruzzo is a region in Italy that has a fairly developed forest sector and a huge forest surface (about $41 \%$ of the region) accounting for about $4 \%$ of the entire Italian forest surface. In this region, there are about 19,158 ha of coniferous plantations, and of these, black pine afforestation covers about 13,004 ha [44]. The pine afforestation that was studied covers about 27 ha along the middle mountain slope. The two blocks that were chosen for the experiment are located on the southeastern slope in the altitudinal range of 1200-1300 $\mathrm{m}$ a.s.1. (above sea level), with an average slope of about $50 \%$. On the slope are three different calcareous formations dating back to the Triassic-Jurassic: lower limestone calcareous, ammonite green, limestone, Posidonia marl, and Corniola. In some portions, there is generally stratified and cemented Pleistocene stratum debris consisting of gravels and breccias, predominantly limestone.

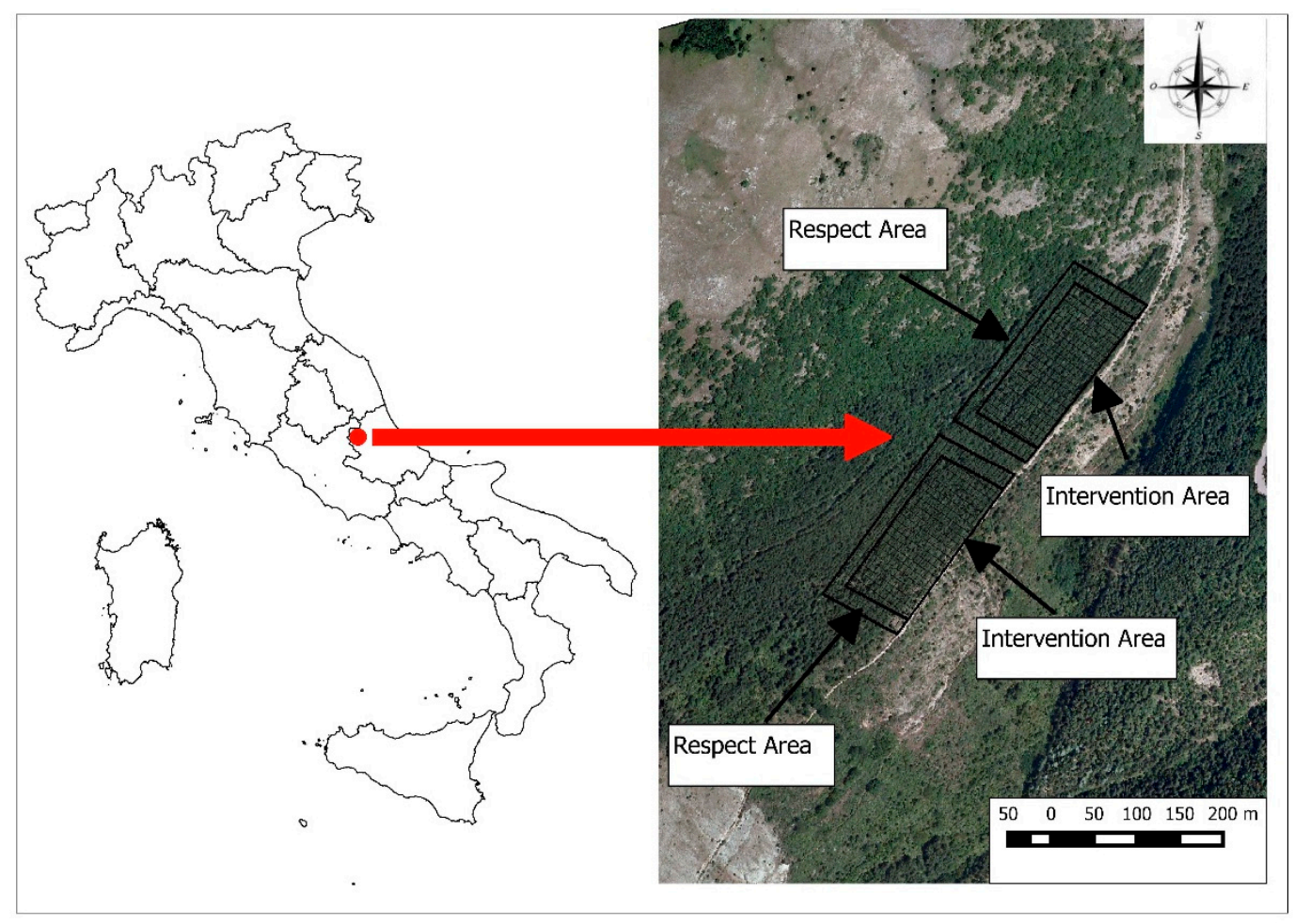

Figure 1. Geographical information and detailed scheme of the treatment area.

A general climatic analysis of the area was conducted on the basis of data available from the meteorological stations of Montereale and Assergi, relating to the years 1950-2000. Rainfall has a bimodal regime, with two annual maximums, in April and November. The driest month is usually July, with about $40 \mathrm{~mm}$ of precipitation, and only six rainy days. The winter cold has remarkable peaks, with monthly averages of minimum air temperatures lower than $0^{\circ} \mathrm{C}$ for four months; average daily temperatures below $10^{\circ} \mathrm{C}$ are exhibited for six months. From the study of the Mitrakos diagrams, it appears that the maximum cold stress was reached only in the month of January, whereas aridity stress was in July. The classification in Rivas-Martínez [45] was used for the bioclimatic description, which defines the considered area as a continental temperate bioclimate, and more precisely as within the attenuated subcontinent subtype. The thermo type was found to be supratemperate lower and ombrotype humid. Additional details regarding temperature and precipitation values throughout the years of the study period are reported in Table 1. 
Table 1. Detailed information regarding temperature and precipitation values throughout the years of the study period.

\begin{tabular}{ccccccc}
\hline Years & $\mathbf{2 0 1 5}$ & $\mathbf{2 0 1 6}$ & $\mathbf{2 0 1 7}$ & $\mathbf{2 0 1 5}$ & $\mathbf{2 0 1 6}$ & $\mathbf{2 0 1 7}$ \\
\hline Months & \multicolumn{2}{c}{ Temperature $\left({ }^{\circ} \mathbf{C}\right)(\mathbf{m i n} / \mathbf{m e a n} / \mathbf{m a x})$} & \multicolumn{2}{c}{ Precipitation $(\mathbf{m m})$} & Total \\
\hline 1 & $-10.0 / 2.8 / 14.0$ & $-8.0 / 4.9 / 15.0$ & $-3.1 / 0.1 / 4.4$ & 69.5 & 70.1 & 7.5 \\
2 & $-5.0 / 5.2 / 11.0$ & $-3.0 / 7.9 / 18.0$ & $2.5 / 6.6 / 11.5$ & 67.6 & 72.9 & 0 \\
3 & $-1.2 / 10.1 / 20.1$ & $-0.4 / 10.8 / 23.1$ & $2.6 / 9.0 / 16.0$ & 67.1 & 66.8 & 0 \\
4 & $1.0 / 10.8 / 24.2$ & $-1.1 / 11.6 / 27.3$ & $4.3 / 10.6 / 17.6$ & 68.9 & 65.5 & 0 \\
5 & $6.1 / 16.6 / 31.2$ & $4.1 / 15.5 / 30.4$ & $8.6 / 14.9 / 21.8$ & 55.1 & 58.8 & 3.2 \\
6 & $10.0 / 20.6 / 30.4$ & $9.1 / 21.4 / 32.2$ & $14.2 / 21.5 / 28.5$ & 45.2 & 46.6 & 0.3 \\
7 & $13.3 / 23.1 / 36.1$ & $11.1 / 22.8 / 34.0$ & $14.8 / 22.5 / 30.1$ & 35.1 & 36.1 & 7.4 \\
8 & $12.3 / 23.2 / 33.4$ & $7.1 / 21.8 / 32.4$ & $16.0 / 24.2 / 32.6$ & 43.2 & 43.4 & 0 \\
9 & $7.1 / 17.9 / 33.2$ & $4.1 / 16.8 / 30.1$ & $10.1 / 15.8 / 21.7$ & 62.1 & 57.2 & 0.2 \\
10 & $4.2 / 12.1 / 22.1$ & $2.2 / 12.6 / 23.4$ & $5.2 / 12.6 / 20.8$ & 89.9 & 89.1 & 0 \\
11 & $-2.0 / 8.5 / 21.3$ & $-2.3 / 8.2 / 19.4$ & $-0.8 / 7.3 / 19.7$ & 85.2 & 88.8 & 10.7 \\
12 & $-5.4 / 4.5 / 13.2$ & $-9.1 / 3.1 / 12.4$ & $-0.8 / 3.3 / 7.9$ & 72.1 & 92.9 & 60.5 \\
\hline
\end{tabular}

The black pine (Pinus nigra Arnold subsp. nigra var. italica Villetta Barrea) plantation studied was about 60 years old. The soil preparation was done in steps (called "gradoni", or small terraces) $2 \mathrm{~m}$ to $4 \mathrm{~m}$ apart, with numerous stone artefacts. The planting was carried out with bare root black pine transplants at a distance of $1 \mathrm{~m}$ in the step. It was a pure stand, with poor social differentiation and a high slenderness ratio, which is a clear sign of a lack of thinning. The degree of coverage was high (90-100\%) and homogeneous. The distance between the trees was similar to the original planting scheme. The shrubby undergrowth was very poor, while dense brachypodium carpets and mosses were intertwined with needles and cones. An analysis conducted on the wooden bores of some trees showed that the annual growth had undergone a significant slowdown in the last eight years (fractions of $\mathrm{mm}$ ), accentuating the slowdown that occurred 16 years ago, and making it difficult to hypothesize a reaction to any thinning. The limit of $60-65$ years represents a threshold beyond which the reaction capacity of the stand to the thinning is greatly reduced [1]. In the considered afforestation, no significant meteoric damage had occurred, there were no obvious signs of fungal and insect attacks, dead wood snags were substantially absent, and logs were not consistent.

\subsection{Renaturalization Treatment and Logging Methods}

Among the possible renaturalization techniques [46], taking into account the stand age, the need to combine harvesting cost-effectiveness, that it was solid ground despite being on a high slope, and that the black pine forest was sheltered from northern winds, clear-cutting (dismantling cutting) on strips was chosen. This consisted of a series of strips $15 \mathrm{~m}$ wide and $100 \mathrm{~m}$ long, alternating with uncut strips (to eliminate $50 \%$ of the surface of the pine plantation). The width was proportional to the tree height, while the length was proportional to the logging systems and planning. The choice of the two experimental blocks was made through a design-based approach, which is a statistical approach that establishes the methods of choice and use of the sites, allowing possible pseudoreplication problems to be overcome [47]. The two experimental blocks (replicates) were delimited upstream of a forest road, and they differed in altitude location, forest growth conditions, and soil texture. The first experimental block, which was at an altitude of $1200 \mathrm{~m}$ a.s.l. (east-southeast), consisted of 12 strips that were $100 \mathrm{~m}$ long (according to the lines of maximum slope) and $15 \mathrm{~m}$ wide. This block was surrounded on all sides, excluding the track, with a protection buffer that was a minimum of $20 \mathrm{~m}$ wide. The second block, with similar characteristics, was realized slightly lower, at an altitude of $1100 \mathrm{~m}$ a.s.l. (southeast). The logging treatments within each block were randomly assigned, while the silvicultural treatments were systematically assigned (one uncut strip and one clear-cut strip). Within each block, the silvicultural treatment was applied on six alternating strips (one harvested and one untouched) to have six silvicultural repetitions and six control areas. In the harvested strips, three logging treatments 
were applied, with two repetitions for every replicate (block). The different extraction methods were characterized by different machines and techniques (detailed in Table 2): (a) animal skidding downhill by TPR (heavy rapid skidding) horse, (b) winching downhill by a forestry-fitted farm tractor using snatch block, and (c) yarding downhill by a cable yarder with automatic carriage. The two blocks (replicates) differed in altitude, soil texture, and dendrometric characteristics.

Table 2. Different extraction methods applied, characterized by different machines and techniques.

\begin{tabular}{|c|c|c|}
\hline Logging Operation & System Detail & Mechanization and Work Team \\
\hline $\mathrm{H}$ & $\begin{array}{l}\text { direct skidding of whole } \\
\text { tree, on forest soil }\end{array}$ & Two operators, by "TPR" horse with mass of about $1200 \mathrm{~kg}$ \\
\hline $\mathrm{W}$ & $\begin{array}{l}\text { indirect skidding of } \\
\text { whole tree, from the } \\
\text { forest road }\end{array}$ & $\begin{array}{l}\text { Two operators, by forestry-fitted farm tractor using snatch } \\
\text { block. Winch of pull force of } 70 \mathrm{kN} \text { and maximum work } \\
\text { distance } 100 \mathrm{~m} \text {, tractor with engine power of } 63 \mathrm{~kW} \text { and } \\
\text { mass of about } 4 \mathrm{t}\end{array}$ \\
\hline $\mathrm{C}$ & $\begin{array}{l}\text { yarding of whole tree, } \\
\text { from the forest road }\end{array}$ & $\begin{array}{l}\text { Two operators, by double drum cable yarder, with } \\
\text { automatic carriage with pull force of } 20 \mathrm{kN} \text { and maximum } \\
\text { line work distance } 600 \mathrm{~m}\end{array}$ \\
\hline
\end{tabular}

H: animal skidding; W: winching downhill by a forestry-fitted farm tractor using snatch block; C: yarding downhill by a cable yarder with automatic carriage.

\subsection{Analytical Methods}

A dendrometric analysis was performed by measuring the diameters at breast height (DBH) of all of the trees, and the plant height of $10 \%$ of the trees, which allowed constructing the hypsometric curve and then determining the growing stock by applying the model tree method.

In order to determine the soil particle size distribution for the studied areas, six soil samples in each block were randomly sampled from the top $30 \mathrm{~cm}$ of the mineral soil, which was considered to be a crucial indicator of vulnerability to soil compaction [48]. Rock fragments (particles $>2 \mathrm{~mm}$ in diameter) were removed from the air-dried samples for particle size distribution. Afterwards, three sand fractions - 2.00-0.50 mm (coarse), 0.50-0.25 mm (medium), and 0.25-0.05 $\mathrm{mm}$ (fine)—were separated by wet sieving. Finally, silt and clay were determined using a hydrometer [31].

Three linear transects, consisting of $1 \mathrm{~m} \times 30 \mathrm{~m}$ rectangles for every harvested strip, were tracked to estimate the tree regeneration community composition and perform quantitative analysis. A systematic sampling method was applied as shown in Figure 2. These post-operation analyses were conducted using research methods based on internationally shared protocols, elaborated, and adapted to this context of study as proposed in $[8,9,25,26,49]$.

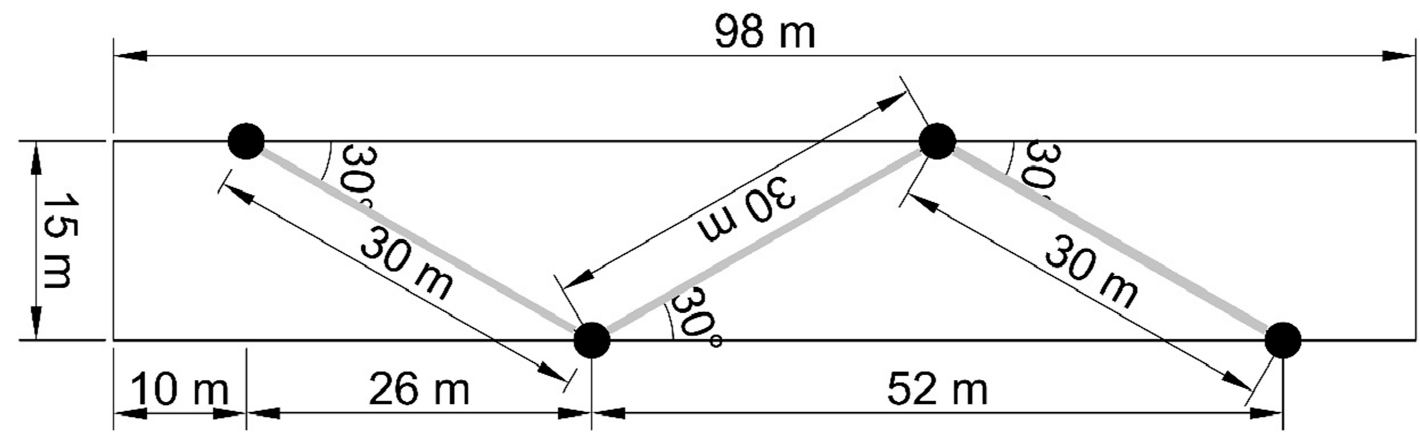

Figure 2. Scheme of the systematic sampling method applied in every harvested strip. The black points are only the starting points of every linear transect (grey lines).

The vegetation study was set up according to the phytosociological method [44]. The surveys were performed in summer, when most of the species were flowering. The analysis was carried out 
in the entire slope of the forest to investigate the potential vegetation and identify the relationships between plant associations and topography that were established between the different vegetation series. Vascular species were recorded with the percentage of coverage-abundance for each area. The phytosociological surveys carried out in the reforestation area allowed us to characterize the current state of the underbrush. The analysis of the groups of species related to the phytosociological syntaxa allowed us to interpret the current phase of reforestation dynamics and its location in the vegetation series that characterizes the area in which the pinewood was located. The floristic study took place through sample collections before cutting. The samples were determined using the main national [50-54] and European flora [54,55].

The tree composition of natural regeneration was analyzed by the Species Importance Value (SIV) index, which was calculated for each species, as reported in the literature [48,56] (Table 3). The regeneration species diversity index was computed using the Shannon-Wiener information function (Table 3).

Table 3. Detailed formulas and descriptions of the Species Importance Value (SIV) index, Regeneration species diversity index and structural evenness index.

\begin{tabular}{|c|c|}
\hline Description & Formula \\
\hline Species Importance Value (SIV) index & Relative density $(\mathrm{RDe})+$ Relative frequency $(\mathrm{RF})+$ Relative dominance (RDo) \\
\hline Relative density (RDe) & $\begin{array}{l}\text { (Number of individuals of a species } \times 100 \text { )/total number of individuals of } \\
\text { all species }\end{array}$ \\
\hline Relative frequency (RF) & $\begin{array}{l}\text { (Number of plots containing a species } \times 100 \text { )/sum of frequencies of } \\
\text { all species }\end{array}$ \\
\hline Relative dominance (RDo) & (Sum of the height of a species $\times 100$ )/sum of total height of all species \\
\hline $\begin{array}{l}\text { Regeneration species diversity index } \\
\text { (Shannon diversity index) }\end{array}$ & $\begin{array}{l}\mathrm{H}^{\prime}=-\Sigma(\mathrm{ni} / \mathrm{n}) \cdot \mathrm{Ln}(\mathrm{ni} / \mathrm{n}) \\
\mathrm{ni}=\text { denotes the SIV of a species and } \\
\mathrm{n}=\text { denotes the sum of the total SIV of all the species }\end{array}$ \\
\hline Structural evenness index & $\begin{array}{l}\mathrm{J}=\mathrm{H}^{\prime} / \mathrm{Hmax} \\
\mathrm{H}^{\prime} \text { is the number derived from the Shannon diversity index and Hmax is the } \\
\text { maximum value of } \mathrm{H}^{\prime}\end{array}$ \\
\hline
\end{tabular}

The natural regeneration and floristic biodiversity of tree composition were also assessed using species richness. The Shannon index and the evenness index were used for floristic biodiversity, without considering the tree layer before cutting. Biodiversity indices were compared by year and type of intervention. Species richness was defined as the total number of species sampled. The Shannon index [57] is based on information theory and the degree of difficulty in accurately predicting the next species sampled. This diversity index is sensitive to changes in rare species, has good discriminant ability, and is well represented in the literature [58]. Biodiversity indices were compared by year and type of intervention. The structural evenness index was calculated as reported in [59] (Table 2). This index varies between 0 and 1, where a value of 1 symbolizes an exact uniform distribution. The Shannon index is a model that measures species diversity and the degree of homogeneity in species abundance. One of its applications is to correctly estimate the anthropogenic impact on ecological systems.

The impact on soil due to silvicultural treatment and forest operations was assessed by a systematic sampling method selecting three sample plots (SPs) for each harvested strip, one every $30 \mathrm{~m}$ along the strip axis, starting at $15 \mathrm{~m}$ from the lower border. Each SP consisted of a circular area $12 \mathrm{~m}$ in diameter. In each SP, three tests for every parameter were done, which measured: bulk density (BD), $\mathrm{pH}$, organic matter content (OM), inorganic carbon content (IC), penetration resistance (PR), and shear resistance (or strength) (SR), and QBS-ar index as detailed in [43-47]. For the two blocks, two different control areas were selected at the edge of the blocks, which were at least $30 \mathrm{~m}$ from the edges. In each area, three SPs were randomly selected, and three tests for all of the parameters were done on each of them. 
Natural regeneration analyses were done in 2016 and 2017, which were one and two years after harvesting, respectively. Soil impact analyses were done in 2015, immediately after the logging operations, and in 2016 and 2017, one and two years after harvesting, respectively. All of the analyses were replicated in the same months.

\subsection{Statistics}

Statistical analyses were carried out using Statistica 7.1 (2007) software (StatSoft Inc., Tulsa, OK, USA). As a first step, data distribution was plotted and checked for normality (Lilliefors) and homogeneity of variance (Levene test). All of the data points then underwent a $t$-test, an ANOVA, or a MANOVA to test the effects of the different treatments. In order to determine the relation between QBS-ar, BD, PR, and SR, a non-parametric correlation analysis (Spearman correlation matrix) was applied. The data, which were not normally distributed and had insufficient homogeneity of variance, were statistically processed using the non-parametric ANOVA Kruskal-Wallis test. Principal component analysis (PCA) was applied to investigate any linear correlations between the expressed soil conditions of the main six characteristics studied, and also between the tree regeneration situations of the main four characteristics studied. To minimize the scaling effect due to the different measurement units, the data corresponding to each independent variable were standardized using Box-Cox lambda.

\section{Results}

\subsection{Silvicultural Treatment and Dendrometric Analysis}

The silvicultural treatment applied was clear-cutting (dismantling cutting) on strips, with harvesting of $50 \%$ of the surface of the pine plantation. The strip dimensions were proportioned to the tree height and length to the logging system and planning. This treatment aimed to achieve the renaturalization of these forests within a sustainable management system.

The dendrometric data collected before the harvesting of the two blocks showed average values, which were statistically similar for trees age, DBH tree height, basal area, tree density, and aboveground biomass stock (Table 4).

Table 4. Main dendrometric characteristics of the pine forest before cutting (ANOVA test, df 3, 40; average $\pm \mathrm{SD}$ ). $\mathrm{DBH}$ : diameters at breast height.

\begin{tabular}{|c|c|c|c|c|c|c|c|}
\hline Treatment & Block & $\begin{array}{l}\text { Age } \\
\text { (Year) }\end{array}$ & DBH (m) & Height (m) & $\begin{array}{l}\text { Density } \\
\text { (Trees/ ha) }\end{array}$ & $\begin{array}{l}\text { Basal Area } \\
\left(\mathrm{m}^{2} / \mathrm{ha}\right)\end{array}$ & $\begin{array}{c}\text { Above-Ground } \\
\text { Biomass Stock }\left(\mathrm{m}^{3} / \mathrm{ha}\right)\end{array}$ \\
\hline \multirow[b]{2}{*}{$\mathrm{H}$} & 1 & 60 & $0.24 \pm 0.05^{\mathrm{a}}$ & $14.4 \pm 0.9^{a}$ & $728 \pm 67^{a}$ & $32.9 \pm 8.2^{\mathrm{a}}$ & $308.1 \pm 15.2^{\mathrm{a}}$ \\
\hline & 2 & 60 & $0.19 \pm 0.06^{b}$ & $13.4 \pm 0.6^{\mathrm{b}}$ & $1220 \pm 74^{b}$ & $34.6 \pm 2.2^{b}$ & $301.1 \pm 10.5^{b}$ \\
\hline \multirow{2}{*}{ W } & 1 & 60 & $0.23 \pm 0.07^{a}$ & $14.3 \pm 1.1^{\mathrm{a}}$ & $720 \pm 83^{a}$ & $29.9 \pm 9.1^{c}$ & $277.9 \pm 19.3^{c}$ \\
\hline & 2 & 60 & $0.18 \pm 0.04^{b}$ & $13.2 \pm 0.8^{b}$ & $1232 \pm 91^{b}$ & $31.3 \pm 6.8^{a, c}$ & $268.9 \pm 19.9^{c}$ \\
\hline \multirow{2}{*}{ C } & 1 & 60 & $0.22 \pm 0.08^{a}$ & $14.1 \pm 1.8^{\mathrm{a}}$ & $745 \pm 54^{\mathrm{a}}$ & $28.3 \pm 6.7^{c}$ & $259.4 \pm 21.1^{\mathrm{d}}$ \\
\hline & 2 & 60 & $0.20 \pm 0.08^{b}$ & $13.7 \pm 0.3^{\mathrm{a}, \mathrm{b}}$ & $1228 \pm 47^{b}$ & $38.6 \pm 5.1^{d}$ & $343.4 \pm 10.5^{\mathrm{e}}$ \\
\hline \multirow{2}{*}{ Control } & 1 & 60 & $0.22 \pm 0.05^{\mathrm{a}}$ & $14.1 \pm 1.0^{\mathrm{a}}$ & $729 \pm 25^{a}$ & $27.7 \pm 7.1^{\mathrm{c}}$ & $253.8 \pm 11.1^{\mathrm{d}}$ \\
\hline & 2 & 60 & $0.18 \pm 0.03^{b}$ & $13.2 \pm 0.5^{b}$ & $1231 \pm 32^{b}$ & $31.3 \pm 2.9^{a, c}$ & $268.6 \pm 10.8^{c}$ \\
\hline \multicolumn{3}{|c|}{$p$-value } & $<0.05$ & $<0.05$ & $<0.05$ & $<0.05$ & $<0.05$ \\
\hline
\end{tabular}

Different letters show significant differences among values in a column (Tukey test).

\subsection{Analysis of Stand Regeneration}

No statistical difference was observed between the two blocks, and the nine species were indifferently present $(p>0.05)$. The three logging treatments and the control showed different percentages (ANOVA $p<0.05$ ) of species distribution (Figure 3). The tree species most represented were Sorbus aria L., Fraxinus ornus L., Quercus pubescens Willd., and Quercus cerris L. According to the Tukey test, the strips extracted by cable yarder were statistically grouped with the control data, while the other two treatments were statistically different. Pinus nigra regeneration was largely present in 
the strips extracted by horse $(9 \%)$ and winch $(7 \%)$. There was an exotic tree present in these strips (Robinia pseudoacacia).

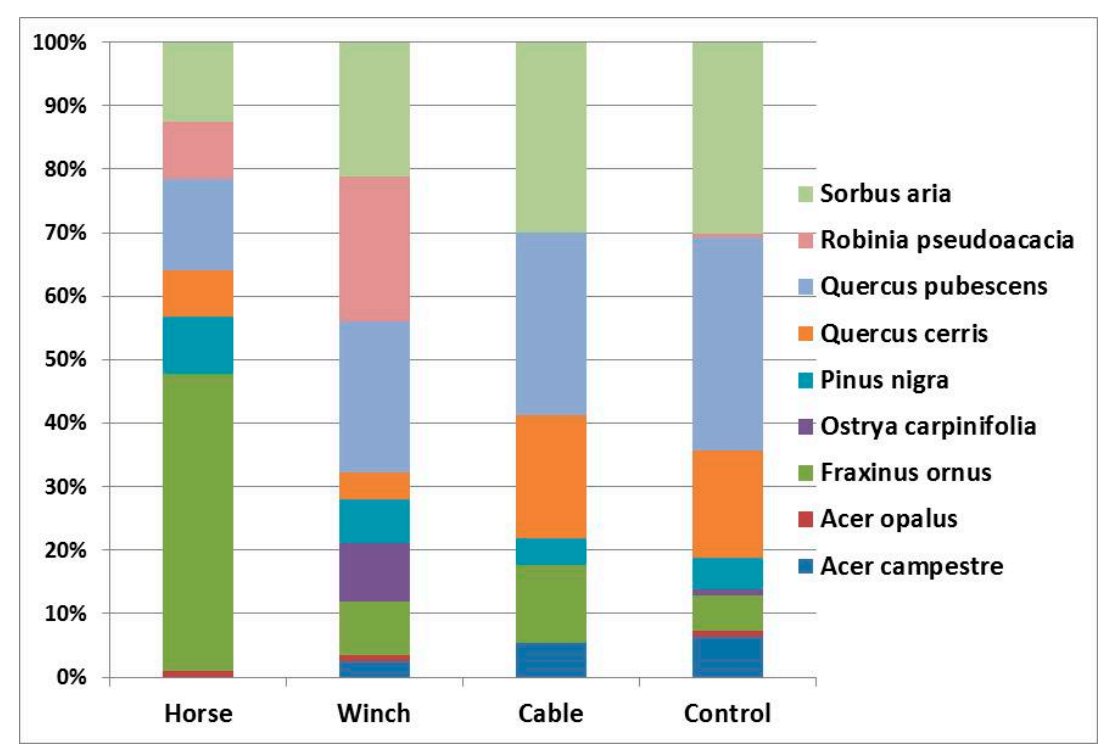

Figure 3. Tree species percentage distribution, average values grouped for logging treatments and control.

One year after harvesting, the highest natural regeneration density was found for the strips extracted by winch and cable yarder: 23,580 trees/ha and 21,150 trees/ha, respectively (Figure 4). The strips extracted by horse showed the lowest value, 6250 trees/ha, and the control had stable values ranging between 10,260-11,150 trees/ha. Two years after harvesting, the highest regeneration density was found for the strips extracted by winch: 20,650 trees/ha, which was slightly lower than in 2016. The strips extracted by horse and cable yarder showed similar values ranging between 18,850-19,170 trees/ha; the first treatment had a considerable increase, while the second one had a slight decrease compared with 2016.

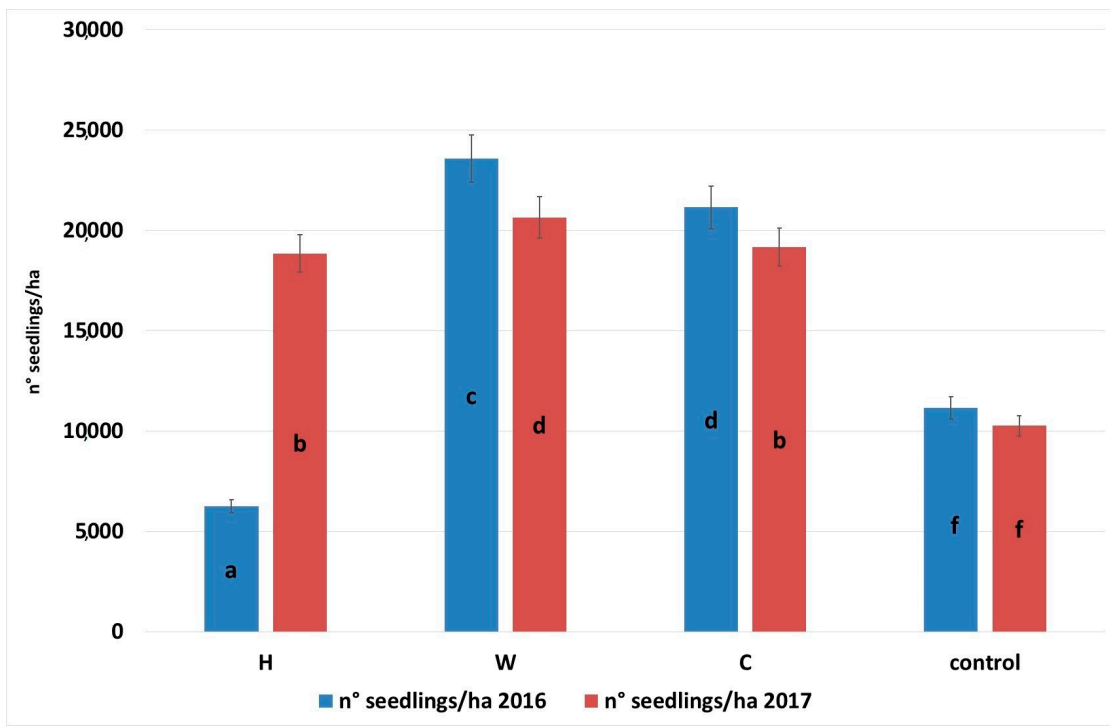

Figure 4. Tree regeneration density, average values with standard deviation for the different treatments, one year after harvesting (2016) and two years after harvesting (2017). ANOVA results shown statistically significant differences, $p<0.05$ and the Tukey test applied found five groups, showed by different letters. 
The SIV detailed analysis for 2017 (Figure 5) shows that the most important tree regeneration was for the species Q. pubescens and Sorbus aria. The worst SIV was shown by Q. cerris and Fraxinus ornus. Fraxinus ornus only showed an SIV peak in the strips extracted by horse. The analysis of the total SIV (Table 5) showed that the strips harvested by horse and winch increased compared to the control, while for the strips harvested by cable yarder, the trend was positive, but the value was lower than the control.

Tree species diversity, as tested by the Shannon-Wiener and the evenness indices, showed different situations. First, there was a general slightly positive trend from 2016 to 2017 for the control and the strips harvested by winch and cable yarder, while the index was stable for the strips harvested by horse. The highest diversity was found for the strips harvested by cable yarder and winch (in particular for the evenness index, amounting to $0.88 \pm 0.07$ and $0.85 \pm 0.09$, respectively, as shown in Table 5), while the lowest diversity was found in the control (Shannon index ranged from 1.68 to 1.70 and the evenness index ranged from 0.73 to 0.77 , Table 5).

Table 5. Tree species diversity indexes for the studied areas (Kruskal-Wallis test analysis, df 3, 144; $p<0.05$; average $\pm \mathrm{SD}$ ).

\begin{tabular}{ccccccc}
\hline \multirow{2}{*}{ Treatments } & \multicolumn{2}{c}{ SIV } & \multicolumn{2}{c}{ Shannon Index } & \multicolumn{2}{c}{ Evenness Index } \\
\cline { 2 - 7 } & $\mathbf{2 0 1 6}$ & $\mathbf{2 0 1 7}$ & $\mathbf{2 0 1 6}$ & $\mathbf{2 0 1 7}$ & $\mathbf{2 0 1 6}$ & $\mathbf{2 0 1 7}$ \\
\hline H & $212^{\mathrm{a}}$ & $214^{\mathrm{a}}$ & $1.60^{\mathrm{a}}$ & $1.58^{\mathrm{a}}$ & $0.81^{\mathrm{a}}$ & $0.81^{\mathrm{a}}$ \\
$\mathrm{W}$ & $205^{\mathrm{b}}$ & $216^{\mathrm{a}}$ & $1.79^{\mathrm{b}}$ & $1.87^{\mathrm{c}}$ & $0.81^{\mathrm{a}}$ & $0.85^{\mathrm{b}}$ \\
$\mathrm{C}$ & $205^{\mathrm{b}}$ & $208^{\mathrm{c}}$ & $1.61^{\mathrm{a}}$ & $1.58^{\mathrm{a}}$ & $0.82^{\mathrm{a}}$ & $0.88^{\mathrm{b}}$ \\
Control & $215^{\mathrm{a}}$ & $213^{\mathrm{a}}$ & $1.68^{\mathrm{d}}$ & $1.70^{\mathrm{d}}$ & $0.73^{\mathrm{c}}$ & $0.77^{\mathrm{c}}$ \\
\hline
\end{tabular}

Different letters show significant differences among values in a column (Tukey test).

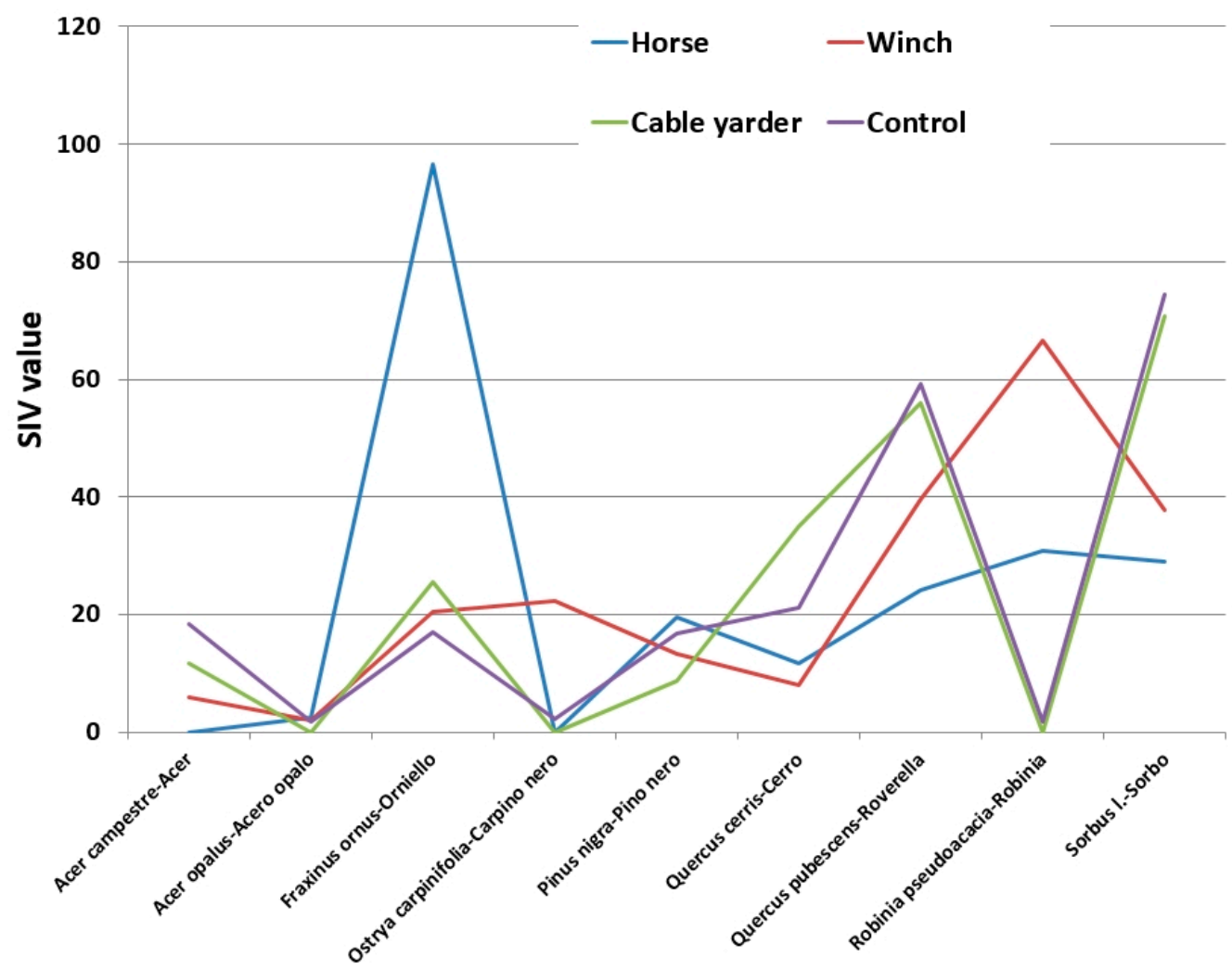

Figure 5. SIV detailed analysis between the treatments and the control for the year 2017. 


\subsection{Analysis of Floristic Biodiversity}

The most consistent group of species, by both qualitative and quantitative analysis, taking into account coverage, was arid secondary grazed meadows (Figure 6). The pool of diagnostic species of the Apennine Phleo ambigui-Bromion erecti alliance was highlighted, among which the graminaceous Brachypodium rupestre was relevant, forming a fairly uniform mat. It was accompanied by Cytisus spinescens, Asperula purpurea subsp. purpurea, and Galium lucidum subsp. lucidum. The group of plants belonging to the superior categories of the suborder Artemisio albae-Bromenalia, order Phleo ambigui-Brometalia erecti, and class Festuco-Brometea was very abundant. Among these, the species forming the structure of secondary grasslands in the Apennines was Bromus erectus. Even if this vegetation was attributable to the Phleo ambigui-Bromion erecti alliance, the difference was the presence in the pinewood of a community dominated by Brachypodium rupestre, which was absent in the pasture. This vegetation settled and became dominant in the stations with a more advanced soil type and a higher water content than that in the Apennines. Therefore, it was less xeric, and had a more closed structure compared to the xeric meadows, highlighting the effect of the tree cover.

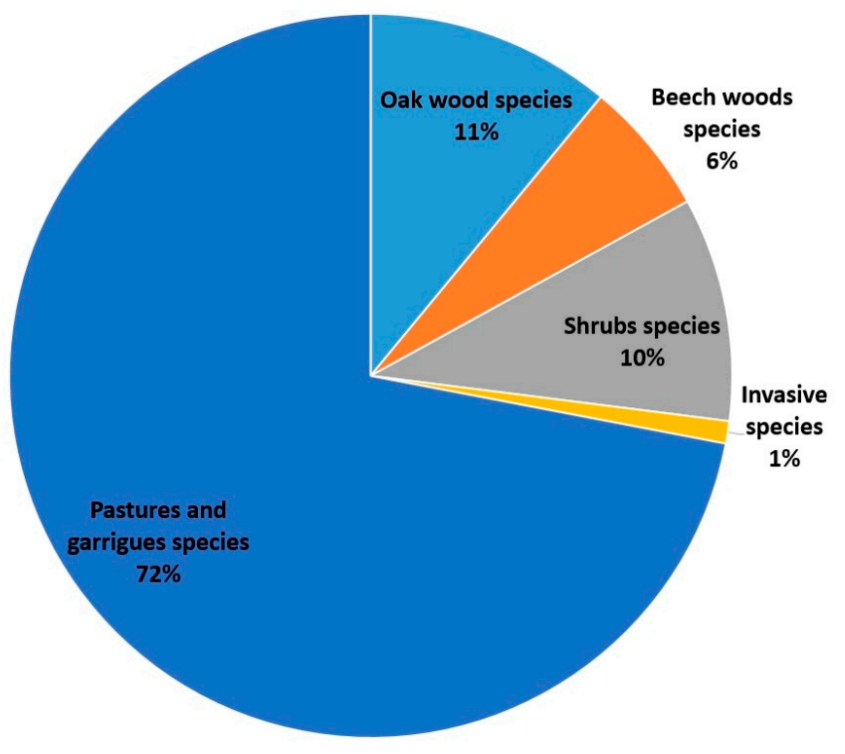

Figure 6. Phytosociological surveys carried out in the afforested area and analysis of the groups of species related to the phytosociological syntaxa.

The results show a constant increase in species richness after cutting (Table 6). This increase does not correspond to an increase in the values of the biodiversity indices, which showed a sharp decline after cutting. However, these values reached higher values after two years before pre-cutting.

A decrease in the values of floristic biodiversity was more evident in the strips harvested by horse, as shown in Figure 7. On the contrary, in the strips where the collection of material was carried out by cable yarder, there was no decrease in Shannon index values (Table 6), but even after the second year, the greatest increases occurred for both indices.

Table 6. Floristic species diversity indexes for the studied areas.

\begin{tabular}{cccccccccc}
\hline & \multicolumn{3}{c}{ Species Richness } & \multicolumn{3}{c}{ Shannon Index } & \multicolumn{3}{c}{ Evenness } \\
\cline { 2 - 10 } Treatments & $\begin{array}{c}\text { Before } \\
\text { Cutting }\end{array}$ & $\begin{array}{c}\text { 1 Year } \\
\text { After }\end{array}$ & $\begin{array}{c}\text { 2 Years } \\
\text { After }\end{array}$ & $\begin{array}{c}\text { Before } \\
\text { Cutting }\end{array}$ & $\begin{array}{c}\text { 1 Year } \\
\text { After }\end{array}$ & $\begin{array}{c}\text { 2 Years } \\
\text { After }\end{array}$ & $\begin{array}{c}\text { Before } \\
\text { Cutting }\end{array}$ & $\begin{array}{c}\text { 1 Year } \\
\text { After }\end{array}$ & $\begin{array}{c}\text { 2 Years } \\
\text { After }\end{array}$ \\
\hline All & 29.92 & 34.75 & 36.83 & 2.03 & 1.91 & 2.08 & 0.6 & 0.54 & 0.58 \\
Horses & 29.67 & 32.00 & 34.67 & 2.07 & 1.82 & 1.90 & 0.61 & 0.53 & 0.54 \\
Winch & 25.33 & 30.00 & 36.00 & 1.91 & 1.91 & 2.13 & 0.59 & 0.56 & 0.59 \\
Cable Yarder & 35.00 & 45.00 & 42.00 & 2.09 & 2.09 & 2.39 & 0.59 & 0.55 & 0.64 \\
\hline
\end{tabular}




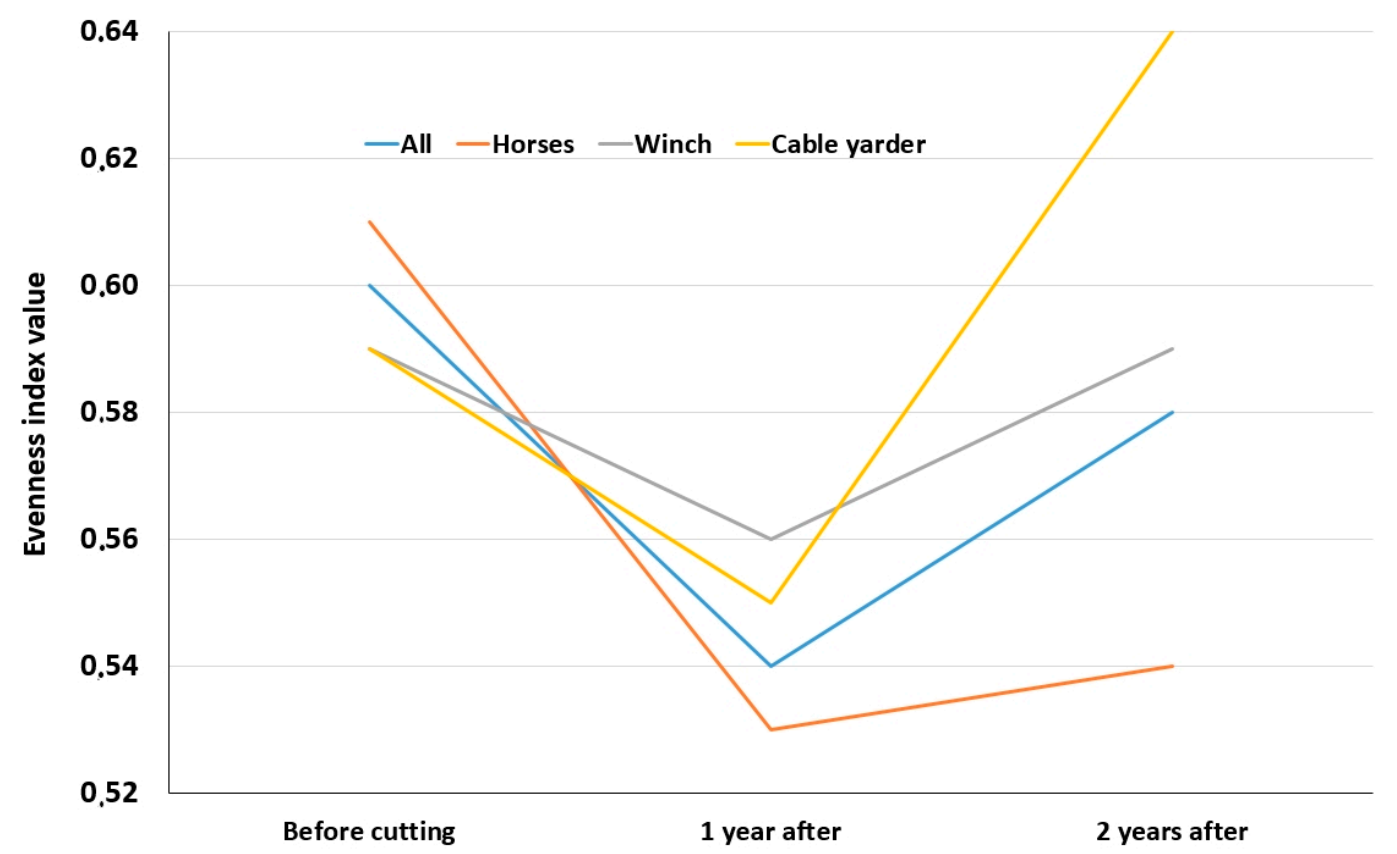

Figure 7. Floristic evenness index trend related to the different harvesting systems.

\subsection{Physical and Chemical Analyses of Soil}

Soil texture was characterized by a high content of rocky skeleton for both blocks ( $48.6 \pm 17.3 \%$ ), while sand, silt, and clay content were statistically different between the two blocks $(p<0.05)$. In block 1 , sand was $59.2 \pm 1.4 \%$, silt was $33.7 \pm 1.3 \%$, and the clay was $7.0 \pm 1.1 \%$. Thus, the soil can be assigned to the sand loam (SaLo) soil material class. In block 2, the sand was $36.6 \pm 3.7 \%$, the silt was $59.4 \pm 3.6 \%$, and the clay was $4.0 \pm 1.3 \%$. Thus, the soil can be assigned to the silt loam (SiLo) soil material class. Relative to the granulometric values and the soil water method (K. Saxton), the soil field capacity (CC) was calculated at $24 \%$ and $27 \%$, respectively.

For each year, sampling was done once in spring, once in summer, and once in autumn. During the sampling periods $(2015,2016$, and 2017) soil moisture showed significant differences $(p<0.05)$ between spring and autumn (average moisture $31 \pm 5 \%$ ) and summer (average moisture $22 \pm 3 \%$ ).

Soil BD showed significant differences only among treatments and years (Table 7). In particular, in the strips harvested by horse, BD was higher than the control and the strips harvested by winch and cable yarder. Nevertheless, in 2017, a recovery trend was highlighted. In the strips harvested by winch, the BD was similar to that of strips harvested by cable yarder, but in 2017, no clear recovery trend was shown. In the strips harvested by cable yarder, BD was higher than that of the control, but lower than that of the strips harvested by horse and winch, although in 2017, a complete recovery was shown.

Table 7. Results of the ANOVA and Tukey test for soil bulk density (BD) during the three years after felling (df 3, 144; average \pm SD), difference tested between the soil of the harvested area, and control.

\begin{tabular}{ccccc}
\hline Treatments & $\begin{array}{c}\text { Bulk Density 2015 } \\
\left(\mathbf{g} / \mathbf{c m}^{3}\right)\end{array}$ & $\begin{array}{c}\text { Bulk Density 2016 } \\
\left(\mathbf{g} / \mathbf{c m}^{3}\right)\end{array}$ & $\begin{array}{c}\text { Bulk Density 2017 } \\
\left(\mathbf{g} / \mathbf{c m}^{\mathbf{3}}\right)\end{array}$ & $p$-Value \\
\hline $\mathrm{H}$ & $1.133 \pm 0.08^{\mathrm{a}}$ & $1.069 \pm 0.09^{\mathrm{d}}$ & $0.962 \pm 0.03^{\mathrm{b}}$ & \\
$\mathrm{W}$ & $0.946 \pm 0.11^{\mathrm{b}}$ & $0.945 \pm 0.09^{\mathrm{b}}$ & $0.928 \pm 0.02^{\mathrm{b}}$ & $<0.05$ \\
$\mathrm{C}$ & $0.947 \pm 0.09^{\mathrm{b}}$ & $0.913 \pm 0.09^{\mathrm{b}}$ & $0.867 \pm 0.02^{\mathrm{c}}$ & \\
Control & $0.853 \pm 0.10^{\mathrm{c}}$ & $0.866 \pm 0.02^{\mathrm{c}}$ & $0.878 \pm 0.01^{\mathrm{c}}$ & \\
\hline$p$-value & $<0.01$ & $<0.01$ & $<0.05$ & \\
\hline
\end{tabular}

Different letters show significant differences among values in a column (Tukey test). 
Soil PR showed statistically significant differences only among treatments and years (Table 8). In particular, in the strips harvested by horse, PR was higher than that of the control as well as the strips harvested by winch and cable yarder. Nevertheless, in 2017, no clear recovery trend was shown. In the strips harvested by winch, the PR was similar to that of the control from 2015. In the strips harvested by cable yarder, in 2015, the PR was higher than that of the control and strips harvested by winch, but lower than that of the strips harvested by horse, although in 2017, a complete recovery was shown.

Table 8. Results of the ANOVA and Tukey test for soil penetration resistance during the three years after felling (df 3, 144; average \pm SD), difference tested between the soil of the harvested area, and control.

\begin{tabular}{ccccc}
\hline Treatments & $\begin{array}{c}\text { Penetration } \\
\text { Resistance 2015 (MPa) }\end{array}$ & $\begin{array}{c}\text { Penetration } \\
\text { Resistance 2016 (MPa) }\end{array}$ & $\begin{array}{c}\text { Penetration } \\
\text { Resistance 2017 (MPa) }\end{array}$ & $\boldsymbol{p}$-Value \\
\hline $\mathrm{H}$ & $0.177 \pm 0.06^{\mathrm{a}}$ & $0.177 \pm 0.08^{\mathrm{a}}$ & $0.175 \pm 0.06^{\mathrm{a}}$ & \\
$\mathrm{W}$ & $0.161 \pm 0.02^{\mathrm{b}}$ & $0.161 \pm 0.03^{\mathrm{b}}$ & $0.160 \pm 0.03^{\mathrm{b}}$ & $<0.05$ \\
$\mathrm{C}$ & $0.169 \pm 0.09^{\mathrm{c}}$ & $0.165 \pm 0.07^{\mathrm{b}, \mathrm{c}}$ & $0.162 \pm 0.03^{\mathrm{b}}$ & \\
Control & $0.160 \pm 0.07^{\mathrm{b}}$ & $0.160 \pm 0.05^{\mathrm{b}}$ & $0.159 \pm 0.03^{\mathrm{b}}$ & \\
\hline$p$-value & $<0.05$ & $<0.05$ & $<0.05$ \\
\hline \multicolumn{5}{c}{}
\end{tabular}

The soil SR showed statistically significant differences only among treatments and years (Table 9). In particular, in the strips harvested by horse, in 2015 and 2016, SR was higher than that of the control as well as the strips harvested by winch and cable yarder. Nevertheless, in 2017, a complete recovery was shown. In the strips harvested by winch and cable yarder, in 2015, SR was higher than that of the control, although already in 2016, a complete recovery was shown.

Table 9. Results of the ANOVA and Tukey test for soil shear resistance during the three years after felling (df 3, 144; average $\pm \mathrm{SD}$ ), difference tested between soil of harvested area, and control.

\begin{tabular}{ccccc}
\hline Treatments & $\begin{array}{c}\text { Shear Resistance } \\
\mathbf{2 0 1 5}\left(\mathbf{t} / \mathbf{m}^{\mathbf{2}}\right)\end{array}$ & $\begin{array}{c}\text { Shear Resistance } \\
\mathbf{2 0 1 6}\left(\mathbf{t} / \mathbf{m}^{\mathbf{2}}\right)\end{array}$ & $\begin{array}{c}\text { Shear Resistance } \\
\mathbf{2 0 1 7}\left(\mathbf{t} / \mathbf{m}^{\mathbf{2}}\right)\end{array}$ & $\boldsymbol{p}$-Value \\
\hline $\mathrm{H}$ & $2.963 \pm 0.11^{\mathrm{a}}$ & $2.964 \pm 0.08^{\mathrm{a}}$ & $2.089 \pm 0.95^{\mathrm{c}}$ & \\
$\mathrm{W}$ & $2.294 \pm 0.20^{\mathrm{b}}$ & $2.215 \pm 0.14^{\mathrm{c}}$ & $2.015 \pm 0.12^{\mathrm{c}}$ & $<0.05$ \\
$\mathrm{C}$ & $2.347 \pm 0.12^{\mathrm{b}}$ & $2.245 \pm 0.14^{\mathrm{b}, \mathrm{c}}$ & $2.016 \pm 0.11^{\mathrm{c}}$ & \\
Control & $2.185 \pm 0.11^{\mathrm{c}}$ & $2.122 \pm 0.32^{\mathrm{c}}$ & $2.089 \pm 0.91^{\mathrm{c}}$ & \\
\hline$p$-value & $<0.05$ & $<0.05$ & $>0.05$ \\
\hline \multicolumn{5}{c}{ Different letters show significant differences among values in a column (Tukey test). }
\end{tabular}

The $\mathrm{pH}$ is a very important parameter for the correct functioning of soil, and its variations influence various soil parameters and processes [60]. The $\mathrm{pH}$ values showed statistically significant differences between blocks, treatments, and years. However, this parameter did not seem to be clearly influenced by silvicultural treatment or logging operations (Table 10). The $\mathrm{pH}$ variations were recorded only for 2017.

Soil organic matter content (OM) showed significant differences only among treatments and years (Table 11). In particular, in the strips harvested by horse, in 2015, OM was lower than that of the control as well as the strips harvested by winch and cable yarder, and the trends in 2016 and 2017 were negative. In 2015, in the strips harvested by winch and cable yarder, the OM was lower than the control, but for the strips harvested by winch, the trends in 2016 and 2017 were negative. There was a complete recovery for the strips harvested by cable yarder in 2017. 
Table 10. Results of the ANOVA and Tukey test for $\mathrm{pH}(\mathrm{df} 3,72$; average \pm SD), difference tested between the soil of the harvested area, and control.

\begin{tabular}{|c|c|c|c|c|c|}
\hline Treatments & Block & pH 2015 & pH 2016 & pH 2017 & $p$-Value \\
\hline \multirow{2}{*}{$\mathrm{H}$} & 1 & $6.5 \pm 0.1^{a}$ & $6.4 \pm 0.3^{a}$ & $6.1 \pm 0.6^{b}$ & \multirow{8}{*}{$<0.05$} \\
\hline & 2 & $6.2 \pm 0.2^{b}$ & $6.4 \pm 0.1^{\mathrm{a}}$ & $6.5 \pm 0.3^{\mathrm{a}}$ & \\
\hline \multirow{2}{*}{ W } & 1 & $6.6 \pm 0.2^{a}$ & $6.5 \pm 0.3^{a}$ & $6.5 \pm 0.2^{a}$ & \\
\hline & 2 & $6.5 \pm 0.3^{a}$ & $6.4 \pm 0.2^{\mathrm{a}}$ & $6.1 \pm 0.1^{b}$ & \\
\hline \multirow{2}{*}{$\mathrm{C}$} & 1 & $6.7 \pm 0.1^{c}$ & $6.4 \pm 0.3^{a}$ & $5.5 \pm 0.6^{d}$ & \\
\hline & 2 & $6.2 \pm 0.1^{b}$ & $6.3 \pm 0.1^{a}$ & $6.4 \pm 0.3^{\mathrm{a}}$ & \\
\hline \multirow{2}{*}{ Control } & 1 & $6.5 \pm 0.2^{a}$ & $6.4 \pm 0.7^{\mathrm{a}}$ & $6.0 \pm 0.6^{b}$ & \\
\hline & 2 & $6.9 \pm 0.3^{c}$ & $6.5 \pm 0.5^{a}$ & $6.5 \pm 0.4^{\mathrm{a}}$ & \\
\hline \multicolumn{2}{|c|}{$p$-value } & $<0.05$ & $>0.05$ & $<0.05$ & \\
\hline
\end{tabular}

Different letters show significant differences among values in a column (Tukey test).

Table 11. Results of the ANOVA and Tukey test for organic matter (df 3, 72; average \pm SD), difference tested between the soil of the harvested area, and control.

\begin{tabular}{ccccc}
\hline Treatments & Organic Matter 2015 (\%) & Organic Matter 2016 (\%) & Organic Matter 2017 (\%) & $p$-Value \\
\hline $\mathrm{H}$ & $30.4 \pm 2.5^{\mathrm{a}}$ & $25.8 \pm 2.0^{\mathrm{d}}$ & $24.8 \pm 1.3^{\mathrm{d}}$ & \\
$\mathrm{W}$ & $34.6 \pm 3.2^{\mathrm{b}}$ & $25.6 \pm 6.1^{\mathrm{d}}$ & $17.7 \pm 5.1^{\mathrm{e}}$ & $<0.05$ \\
$\mathrm{C}$ & $33.9 \pm 1.2^{\mathrm{b}}$ & $35.0 \pm 2.1^{\mathrm{b}}$ & $35.3 \pm 5.3^{\mathrm{b}}$ & \\
Control & $38.2^{\mathrm{b}} \pm 2.2^{\mathrm{c}}$ & $38.1 \pm 1.5^{\mathrm{c}}$ & $36.6 \pm 2.5^{\mathrm{b}}$ & \\
\hline$p$-value & $<0.05$ & $<0.05$ & $<0.05$ &
\end{tabular}

Soil inorganic carbon content (IC) analysis was done only in 2017. The results showed significant differences only among the treatments and control (Table 12). In particular, in the strips harvested by horse, the IC was lower than that of strips harvested by cable yarder, but it was higher than that of the strips harvested by winch, and similar to the control.

Table 12. Results of the ANOVA and Tukey test for inorganic carbon (df 3, 24; average \pm SD), difference tested between soil of harvested area and control.

\begin{tabular}{ccc}
\hline Treatments & Total Inorganic Carbon 2017 (\%) & $p$-Value \\
\hline H & $20.2 \pm 3.6^{\mathrm{a}}$ & \\
W & $13.6 \pm 3.3^{\mathrm{b}}$ & $<0.05$ \\
C & $26.4 \pm 2.1^{\mathrm{c}}$ & \\
Control & $22.4 \pm 2.6^{\mathrm{a}}$ & \\
\hline
\end{tabular}

Different letters show significant differences among values in a column (Tukey test).

\subsection{Soil Biodiversity Analysis}

The QBS-ar index (Table 13) showed significant differences only among treatments and years. In particular, in the strips harvested by horse and by winch, in 2015, QBS-ar was higher than that of the strips harvested by cable yarder, and lower than that of the control. In 2016, a strong decrease was recorded for the strips harvested by horse, and a slightly decrease was recorded for those harvested by winch compared to the control. Nevertheless, both showed complete recovery in 2017. For the strips harvested by cable yarder, in 2015 and 2016, QBS-ar was unchanged and lower than the control, but in 2017, its value appreciably increased. 
Table 13. Results of the Kruskal-Wallis and Tukey test for Soil Biological Quality (QBS-ar) index data (df 3, 144; median), difference tested between disturbed, undisturbed, and control soil.

\begin{tabular}{ccccc}
\hline Treatments & QBS-ar Index 2015 & QBS-ar Index 2016 & QBS-ar Index 2017 & $p$-Value \\
\hline H & $193^{\mathrm{a}}$ & $111^{\mathrm{d}}$ & $228^{\mathrm{c}}$ & \\
$\mathrm{W}$ & $195^{\mathrm{a}}$ & $179^{\mathrm{e}}$ & $199^{\mathrm{a}}$ & $<0.01$ \\
$\mathrm{C}$ & $143^{\mathrm{b}}$ & $143^{\mathrm{b}}$ & $179^{\mathrm{e}}$ & \\
Control & $244^{\mathrm{c}}$ & $199^{\mathrm{a}}$ & $244^{\mathrm{c}}$ & \\
\hline$p$-value & $<0.05$ & $<0.01$ & $<0.05$ & \\
\hline
\end{tabular}

Different letters show significant differences among values in a column (Tukey test).

Microarthropod density (Table 14) showed statistically significant differences among treatments and years. In particular, in the harvested strips, the density values were always lower than the control, but the trends were positive from 2015 to 2017. In 2017, density that was more similar to the control was shown in the strips harvested by winch. More time is necessary for the recovery of the strips harvested by horse and by cable yarder.

Table 14. Results of the Kruskal-Wallis and Tukey test for soil microarthropod density data (df 3, 144; median), difference tested between disturbed, undisturbed, and control soil.

\begin{tabular}{|c|c|c|c|c|}
\hline Treatments & $\begin{array}{c}\text { Microarthropod } \\
\text { Density } 2015 \text { (ind } / \mathrm{dm}^{2} \text { ) }\end{array}$ & $\begin{array}{c}\text { Microarthropod } \\
\text { Density } 2016\left(\mathrm{ind} / \mathrm{dm}^{2}\right)\end{array}$ & $\begin{array}{c}\text { Microarthropod } \\
\text { Density } 2017 \text { (ind } / \mathrm{dm}^{2} \text { ) }\end{array}$ & $p$-Value \\
\hline $\mathrm{H}$ & $64^{a}$ & $81^{a}$ & $124^{\mathrm{f}}$ & \multirow{4}{*}{$<0.05$} \\
\hline W & $107^{\mathrm{b}}$ & $159^{d}$ & $161^{d}$ & \\
\hline C & $75^{a}$ & $106^{b}$ & $100^{b}$ & \\
\hline Control & $175^{c}$ & $223^{e}$ & $175^{\mathrm{c}}$ & \\
\hline$p$-value & $<0.01$ & $<0.01$ & $<0.01$ & \\
\hline
\end{tabular}

Different letters show significant differences among values in a column (Tukey test).

\section{Discussion}

The management of pine plantations has strong and variable effects on plant species occurrence and diversity due to plantation and treatment operations, and the alteration of ecological processes caused by changes in the landscape and stand structure [61,62]. Plantations contribute to biodiversity conservation in various ways. In Poorbabaei [63], a high similarity in species composition between plantation and the adjacent natural forest, which is the main source of seed in plantations, was considered. Neighboring plantation and natural forest has resulted in the dispersion of hardwood tree seeds within the plantation.

The results highlight that the good density and richness of tree species in this pine plantation indicate the high potential reached by the stand for biodiversity restoration. Similar results are shown in studies where plantations of native and/or exotic tree species increased biodiversity by promoting woody understory regeneration $[64,65]$. The silvicultural treatment applied in this research showed positive effects on density, richness, and biodiversity of tree species in three years. Logging operations have important effects on regeneration and tree biodiversity, which are the main topics for restoration and renaturalization purposes.

From the results concerning stand regeneration, different taxonomic compositions of the tree forest community among the logging treatments are shown, in particular in the percentage of distribution. A clear simplification with respect to the others is shown in the strips harvested by horse, with the presence of about $45 \%$ Fraxinus ornus. The general finding shows that ground-based logging systems allowed for the presence of Robinia pseudoacacia and only marginal Pinus nigra regeneration. In general, felling produced an abundance of light-demanding species due to the increase of solar radiation [48]. 
In terms of regeneration density, silvicultural treatment showed a positive effect with greater consistency in the strips harvested by winch and cable yarder. When compared to the control, they had increases of $85 \%$ and $72 \%$, respectively. The strips harvested by horse showed a positive trend, with an increase of about $69 \%$ compared to the control.

In this study, attention was paid to other important aspects, such as the richness and diversity of tree species. In particular, silvicultural treatment more positively influenced the richness (an evenness index increase ranging from $5.2 \%$ to $14.3 \%$ ) and marginally influenced diversity. The strips harvested by winch and by cable yarder had higher richness values than the control and the strips harvested by horse.

Floristic biodiversity, which consists of the numerically and structurally consistent presence of species referable to herbaceous vegetation, and is also present in other pine woods of the Aterno Valley [55], suggested a slow evolution or in some cases no evolution in the undergrowth of artificial pine forests. However, one sign of an ongoing evolutionary process can be found in the analysis of species packages of the shrub layer with the presence of entities referable to mantle vegetation, which are shrub-like formations that set up at the edge of the forest or colonize fields and abandoned pastures. These formations had particular importance in the analysis of the dynamic relationships between the various types of Apennine vegetation. This is confirmed by the significant presence of Cytisophyllum sessilifolium, Rosa canina, Amelanchier ovalis subsp. ovalis, Juniperus communis, Juniperus oxycedrus subsp. deltoides, Viburnum lantana, and Prunus spinosa.

In accordance with results of other similar interventions [66,67] in the years following cutting, we observe an increase in the floristic richness linked to the opening of the tree layer. Increased species richness following canopy disturbance is largely attributed to early seral, shade-intolerant herbs and shrubs invading sites to take advantage of increased light conditions [68,69].

It is important to note that the data presented so far concern a limited period of time that does not allow for more structured statistical analyses. More time is needed to evaluate whether the cutting effect on biodiversity will last long, and observe whether non-forest species are able to regenerate when the crown cover tends to close $[70,71]$. The future effects on biodiversity of each treatment will also require more time to be assessed.

The findings show that soil BD, PR, and SR were influenced by both silvicultural treatment and logging operations. In particular, silvicultural treatment had an impact mainly in the first year post-harvesting, and after two and three years post-harvesting. Recovery was shown, as also found in other studies [44,48]. Among the strips harvested by winch and by cable yarder, only a few differences were found, and the values after three years were similar to the control. The strips harvested by horse showed an important impact in the first year, and the recovery was much slower. Similar values and situations have been observed in other studies, where logs were skidded and vehicles or animals were moved across the forest soil $[9,31]$.

From the data analysis concerning $\mathrm{pH}, \mathrm{OM}$, and IC content, it was possible to note different behaviors among the variables. The $\mathrm{pH}$ values, as found in other studies $[44,48,72]$, did not show any statistical relation to treatments, periods, or blocks. OM content was affected by both silvicultural treatment and logging operations. In particular, silvicultural treatment had an impact mainly in the first year post-harvesting only for the strips harvested by cable yarder, and recovery was reached after two years post-harvesting. For the strips harvested by horse and by winch (ground-based extraction), a negative effect was highlighted in the first year post-harvesting. The trends in the following years were negative, which was mainly attributable to the partial remixing of the superficial soil layers. These negative effects in the first year were due to the silvicultural treatment and the logging operations, while in the following years, the ground-based extraction systems negatively affected OM content, due to partial litter removal [73]. IC content seemed to be affected mainly by the logging operations, and ground-based systems in particular. In the short term, the ground-based extraction systems that cause the mixing of the litter with the soil superficial layers (horse and mainly winch) seem to have a 
negative effect on the IC content. The loss of tree cover, on the contrary, where no litter mixing (cable yarder) is observed, seems instead to increase the IC content in the short term.

The QBS-ar values show a significant positive correlation with soil physical parameters according to the literature $[44,74]$. The observed variation is explained by the different degrees of soil compaction and the abundance of litter associated with sudden stand removal. This mainly affected the strips harvested by cable yarder. In addition to the QBS-ar index, population density was evaluated during sampling in terms of individuals per $\mathrm{dm}^{2}$. As can be observed from the data gathered, microarthropod density was inferior in all of the areas involved in the impact caused by the extraction activities. There was a significant difference between the logging operations, for both the QBS-ar index and population density. The strips harvested by winch had higher values than those harvested by horse and cable yarder. In particular, the values recorded in the strips extracted by cable yarder were lower with respect to the control and the other extraction systems. This is mainly due to the concomitant effect of removing the tree cover and maintaining the pine litter in its original condition. In this study, soil compaction and uncovering led to the rarefaction of specialized groups such as Protura, Diplura, and Pauropoda, and between the logging operations, no particular difference is shown. However, regarding microarthropod density, this index did not efficiently describe the conditions in terms of soil biodiversity. The values that it assumes should be interpreted in terms of trend over time.

Two principal component analyses (PCAs) were carried out to investigate any linear correlations between the expressed soil conditions of the main six studied traits, and between the tree regeneration situations of the main four studied traits. Data corresponding to each independent variable were standardized using Box-Cox lambda to minimize the scaling effect due to the different measurement units. For the soil conditions, the principal components, PC1 and PC2, explained $68 \%$ and $22 \%$ of the total variance, respectively. The PC1 and PC2 scores for the three logging operations and the control are shown in Figure 8. Each logging operation condition is distinct from the other two and from the control based on the score plot, as depicted in Figure 8. In general, a positive trend is shown from 2015 to 2017. In particular, strips harvested by winch and cable yarder showed higher recovery, and for some parameters, the recovery was complete. In detail, the strips harvested by cable yarder had a higher recovery in their physical soil parameters, which implies that these parameters were closely associated with their PC1 scores, according to Marchi [75]. Similarly, the ground-based extraction systems (horse and winch) had a higher recovery of the biological soil parameters that were closely associated with their PC2 scores.

For the tree regeneration situations, the principal components, PC1 and PC2, explained $66 \%$ and $30 \%$ of the total variance, respectively. The PC1 and PC2 scores for the three different logging operations and the control are shown in Figure 9. The tree regeneration situation was similar among the strips harvested by cable yarder and winch. The situation for the strips harvested by horse was similar to the control in 2016, and showed an implementation in 2017 that approached the values of the other two logging operations based on the score plot (Figure 9). In general, a positive trend can be associated with stand harvesting. In detail, the strips harvested by cable yarder and winch had a higher score for tree regeneration density and in the evenness index. These parameters are closely associated with the PC2 axis. SIV values are always associated with the PC2 axis, but with an inverse relation. The Shannon index is closely associated with PC1 scores, and it only shows the best situation for the strips harvested by winch.

Properly managed and programmed clear-cutting within silvicultural systems, such as the strip clear-cutting described here, can positively influence sustainability. This work indicates that less invasive extraction systems (i.e., cable yarder, forest winch) also inflict the least damage on forest soils. 


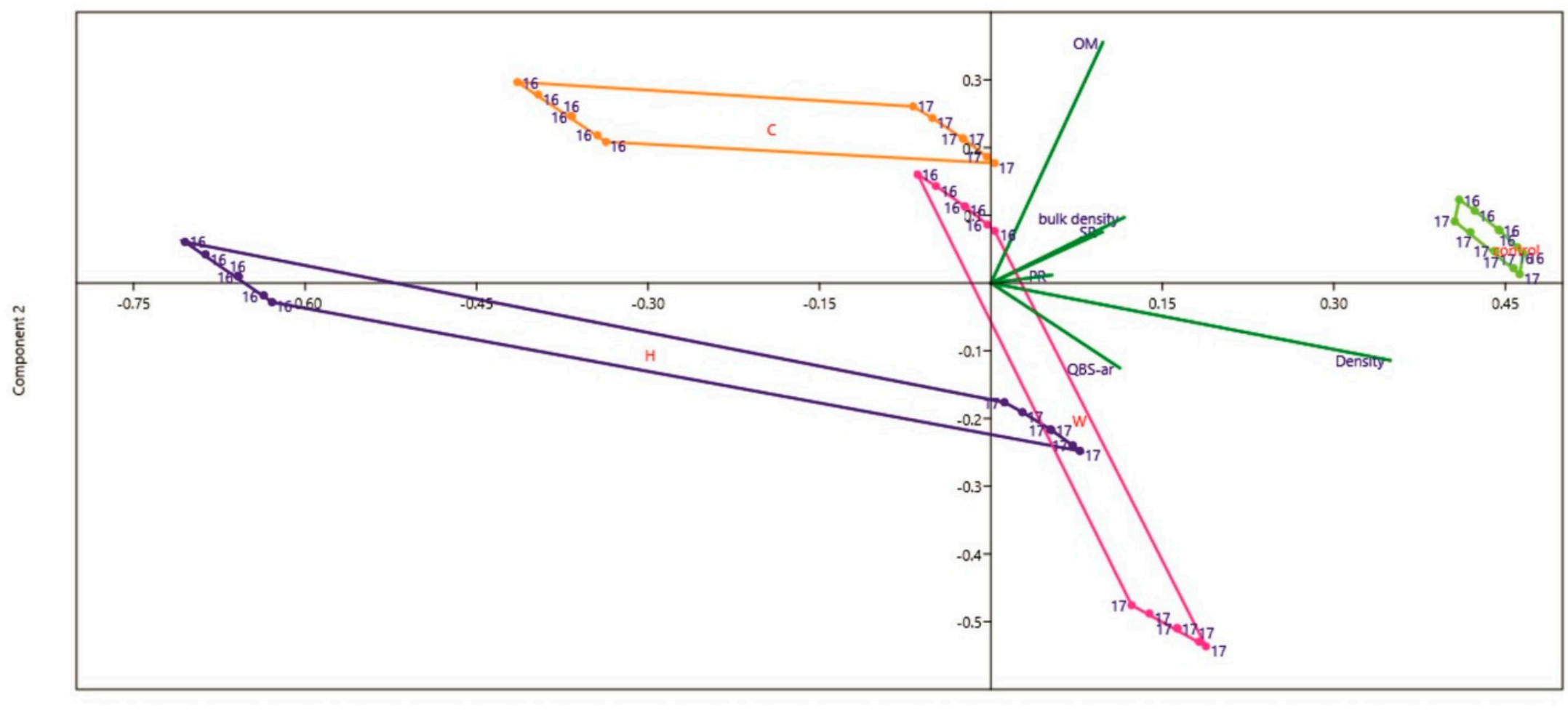

Component 1

Figure 8. Score plot of the components PC1 and PC2 of the principal component analysis referred to soil characteristics. C (orange): strips harvested by cable yarder; W (pink): strips harvested by winch; H (violet): strips harvested by horse; Control (green): stand not harvested. The numbers 16 and 17 represent the years 2016 and 2017, respectively. 


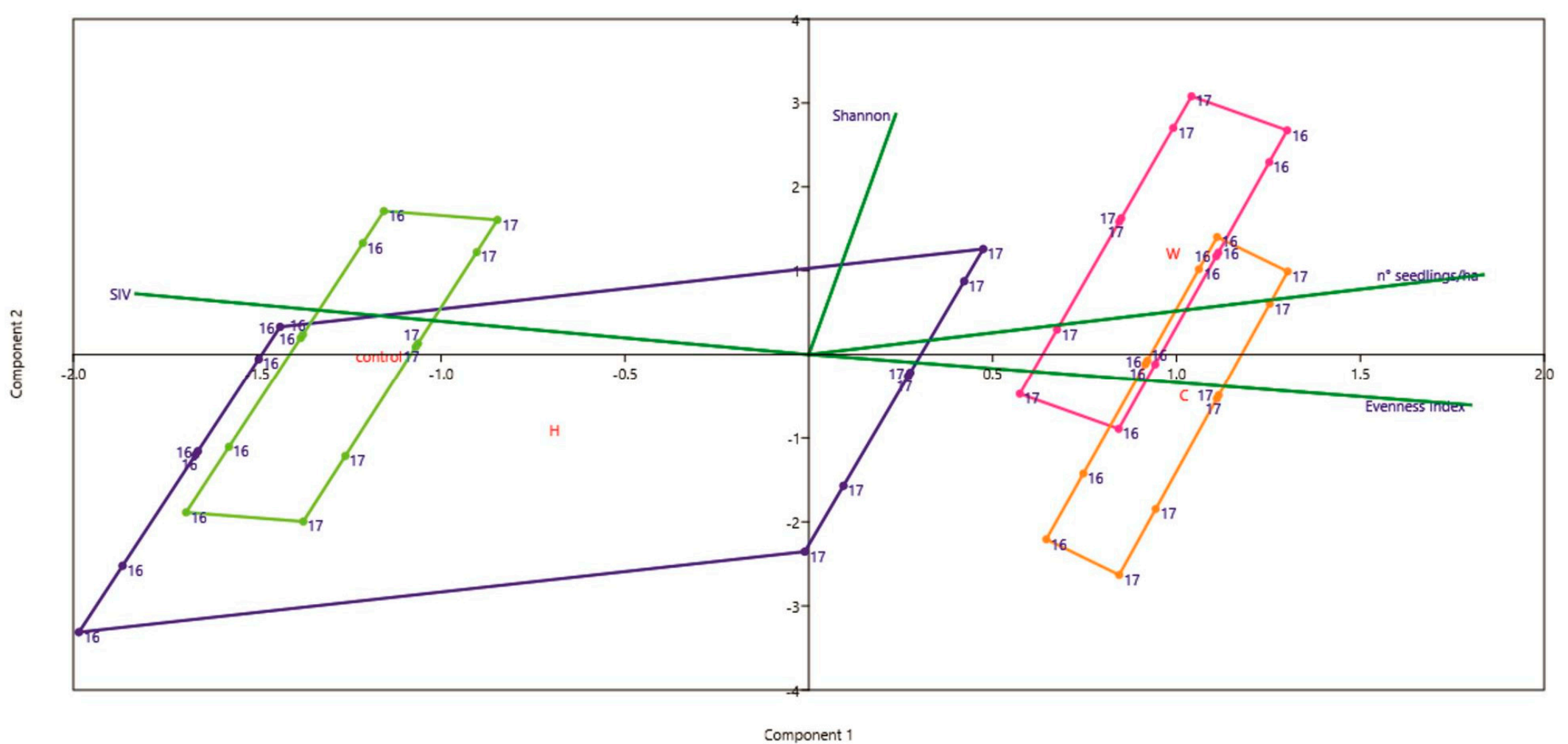

Figure 9. Score plot of the components PC1 and PC2 of the principal component analysis referred to tree regeneration situations. C (orange): strips harvested by cable yarder; $\mathrm{W}$ (pink): strips harvested by winch; $\mathrm{H}$ (violet): strips harvested by horse; Control (green): stand not harvested. The numbers 16 and 17 represent the years 2016 and 2017 respectively. 


\section{Conclusions}

Renaturalization treatments in black pine afforestation is an important topic that should be considered. There is a need to favor the evolution of artificial pine forests toward natural forest systems. The original main purpose of these plantations was to maintain and improve soil characteristics to encourage more complex forest systems. This shift from even-aged pine monocultures to a mixed forest type through natural regeneration is the final goal of these plantations. In Italy in recent years, this substitution has been planned by means of thinning, whereas clear-cutting has been used less. However, the limit of 60-65 years represents the threshold beyond which the reaction capacity of the stand to thinning is greatly reduced, especially in low-fertility areas.

On the whole, this study focused on pine forests and tried to suggest one typology of clear-cutting (dismantling cutting) on strips associated with different extraction management techniques. Some ecological and environmental aspects associated with renaturalization treatments, including techniques applied by different mechanizations in black pine afforestation, have been highlighted as well as how the renaturalization and the active ecological management of these stands could affect soil and vegetation. An outline of answers to the main research questions is as follows:

- In terms of immediate impact on soil features, the less invasive extraction systems seem to be cable yarder and forest winch.

- A clear soil recovery trend with good capability was visible, in particular for the two extraction systems by cable. However, over a three-year period, only a partial but substantial recovery was shown. The main physical soil characteristics reached quick recovery in particular for the strips harvested by cable yarder and forest winch; the organic matter content highlighted a heavy impact, but only for the strips harvested by horse and forest winch. The biological soil characteristics, in particular arthropod communities, still showed a clear impact, which was more highlighted in the strips harvested by cable yarder

- Silvicultural treatment, particularly logging activities, affected natural tree regeneration in a different way. In general, silvicultural treatment showed qualitative and quantitative improvement in terms of tree regeneration. In particular, the extraction systems by forest winch and cable yarder showed better situations

- Silvicultural treatment seems not to have led to improvements at the level of the herbaceous and shrubby layers. However, clear differences are shown among the different harvesting systems. In particular, the strips harvested by cable yarder showed clear recovery, in terms of positive compositions and quantities, whereas the situation was slightly worse for the strips harvested by forest winch, and definitely worse for the strips harvested by horse.

It is important to highlight that the data concern a limited period of time that does not allow for more structured statistical analyses. More time is needed to evaluate whether cutting has more effects. This first step of the research was planned in order to obtain an overview in terms of the environmental impacts related to multifunctional approaches to the forest management of black pine afforestation.

Author Contributions: Conceptualization, R.P., R.M., L.G. and A.R.F.; Methodology, R.P., R.M., L.G. and A.R.F.; Validation, R.P., R.V. and A.L.M.; Investigation, R.P., R.V., T.G. and A.R.F.; Data Curation, R.P., R.V., A.L.M. and A.R.F.; Writing-Original Draft Preparation, R.P., R.M., L.G., T.G., A.R.F. and A.L.M.; Writing-Review \& Editing, R.P., R.V. and A.L.M.; Supervision, R.P., R.M. and A.R.F.

Funding: This research received funding by European Agricultural Fund for Rural Development (PSR-EAFRD 2007-2013) Abruzzo Region, Mes. 124, Project “MORINABIO”.

Conflicts of Interest: The authors declare no conflict of interest. 


\section{References}

1. Del Favero, R. I Boschi Delle Regioni dell'Italia Centrale. Tipologia, Funzionamento, Selvicoltura (Forests in the Regions of Central Italy); CLUEP: Padova, Italy, 2010. (In Italian)

2. Mercurio, R.; Schirone, B. Black Pine Afforestations in Abruzzo (Central Italy): Perspectives and Management. J. Environ. Sci. Eng. 2015, 4, 494-500. [CrossRef]

3. Italian National Forest Inventory (INFC). Inventario Nazionale Delle Foreste E Dei Serbatoi Forestali Di Carbonio (Forest Area Estimates 2005-Section 1. MiPAF-Corpo Forestale dello Stato-Ispettorato Generale, CRA-ISAFA); Italian National Forest Inventory (INFC): Trento, Italy, 2007; pp. 1-413. (In Italian)

4. Tonon, G.; Panzacchi, P.; Grassi, G.; Gianfranco, M.; Cantoni, L.; Bagnaresi, U. Spatial dynamics of late successional species under Pinus nigra stands in the northern Apennines (Italy). Ann. For. Sci. 2005, 62, 669-679. [CrossRef]

5. Collalti, D.; D’Alessandro, L.; Marchetti, M.; Sebastiani, A. La Carta Tipologico-Forestale della Regione Abruzzo; Abruzzo Region, Italy, 2009. Available online: http:/ /geoportale.regione.abruzzo.it/Cartanet/ catalogo/agricoltura-uso-del-suolo/carta-tipologico-forestale-della-regione-abruzzo-1 (accessed on 15 February 2018).

6. Muscolo, A.; Settineri, G.; Bagnato, S.; Mercurio, R.; Sidari, M. Use of canopy gap openings to restore coniferous stands in Mediterranean environment. iForest 2017. [CrossRef]

7. Frey, B.; Niklaus, P.A.; Kremer, J.; Lüscher, P.; Zimmermann, S. Heavy-machinery traffic impacts methane emissions as well as methanogen abundance and community structure in oxic forest soils. Appl. Environ. Microbiol. 2011, 77, 6060-6068. [CrossRef] [PubMed]

8. Picchio, R.; Magagnotti, N.; Sirna, A.; Spinelli, R. Improved winching technique to reduce logging damage. Ecol. Eng. 2012, 47, 83-86. [CrossRef]

9. Picchio, R.; Neri, F.; Petrini, E.; Verani, S.; Marchi, E.; Certini, G. Machinery-induced soil compaction in thinning two pine stands in central Italy. For. Ecol. Manag. 2012, 285, 38-43. [CrossRef]

10. Korb, J.E.; Fulé, P.Z.; Gideon, B. Different restoration thinning treatments affect level of soil disturbance in ponderosa pine forests of Northern Arizona, USA. Ecol. Restor. 2007, 25, 43-49. [CrossRef]

11. Klvač, R.; Vrána, P.; Jiroušek, R. Possibilities of using the portable falling weight deflectometer to measure the bearing capacity and compaction of forest soils. J. For. Sci. 2010, 56, 130-136. [CrossRef]

12. Williamson, J.R.; Neilsen, W.A. The influence of forest site on rate and extent of soil compaction and profile disturbance of skid trails during ground-based harvesting. Can. J. For. Res. 2000, 30, 1196-1205. [CrossRef]

13. Grigal, D.F. Effects of extensive forest management on soil productivity. For. Ecol. Manag. 2000, 138, 167-185. [CrossRef]

14. Olajuyigbe, S.; Tobin, B.; Saunders, M.; Nieuwenhuis, M. Forest thinning and soil respiration in a Sitka spruce forest in Ireland. Agric. For. Meteorol. 2012, 157, 86-95. [CrossRef]

15. Muscolo, A.; Bagnato, S.; Sidari, M.; Mercurio, R. A review of the roles of forest canopy gaps. J. For. Res. 2014, 25, 725-736. [CrossRef]

16. Convention on Biological Diversity (CBD). CBD COP 10 Decision X/2 Strategic Plan for Biodiversity 2011-2020; CBD: Nagoya, Japan, 2010.

17. CEC European Community Biodiversity Strategy. 1998. Available online: https://eur-lex.europa.eu/legalcontent/EN/TXT/?uri=LEGISSUM\%3A128183 (accessed on 15 February 2018).

18. Sebek, P.; Bace, R.; Bartos, M.; Benes, J.; Chlumska, Z.; Dolezal, J.; Dvorsky, M.; Cizek, L. Does a minimal intervention approach threaten the biodiversity of protected areas? A multi-taxa short-term response to intervention in temperate oak-dominated forests. For. Ecol. Manag. 2015, 358, 80-89. [CrossRef]

19. Sutherland, W.J.; Pullin, A.S.; Dolman, P.M.; Knight, T.M. The need for evidence-based conservation. Trends Ecol. Evol. 2004, 19, 305-308. [CrossRef] [PubMed]

20. Convention on Biological Diversity (CBD). CBD Sustainable Management of Non-Timber Forest Resources; Technical Series No. 6; Convention on Biological Diversity: Montreal, QC, Canada, 2001.

21. Corona, P.; Chirici, G.; McRoberts, R.E.; Winter, S.; Barbati, A. Contribution of large-scale forest inventories to biodiversity assessment and monitoring. For. Ecol. Manag. 2011, 262, 2061-2069. [CrossRef]

22. Mattioli, W.; Mancini, L.D.; Portoghesi, L.; Corona, P. Biodiversity conservation and forest management: The case of the sweet chestnut coppice stands in Central Italy. Plant Biosyst. 2016, 150, 592-600. [CrossRef] 
23. Cavalli, R.; Grigolato, S. Influence of characteristics and extension of a forest road network on the supply cost of forest woodchips. J. For. Res. 2010, 15, 202-209. [CrossRef]

24. Vusić, D.; Šušnjar, M.; Marchi, E.; Spina, R.; Zečić, T.; Picchio, R. Skidding operations in thinning and shelterwood cut of mixed stands-Work productivity, energy inputs and emissions. Ecol. Eng. 2013, 61, 216-223. [CrossRef]

25. Picchio, R.; Neri, F.; Maesano, M.; Savelli, S.; Sirna, A.; Blasi, S.; Baldini, S.; Marchi, E. Growth effects of thinning damage in a Corsican pine (Pinus laricio Poiret) stand in central Italy. For. Ecol. Manag. 2011, 262, 237-243. [CrossRef]

26. Picchio, R.; Spina, R.; Maesano, M.; Carbone, F.; Lo Monaco, A.; Marchi, E. Stumpage value in the short wood system for the conversion into high forest of an oak coppice. For. Stud. China 2011, 13, 252-262. [CrossRef]

27. Laschi, A.; Marchi, E.; González-García, S. Forest operations in coppice: Environmental assessment of two different logging methods. Sci. Total Environ. 2016, 562, 493-503. [CrossRef] [PubMed]

28. Edlund, J.; Keramati, E.; Servin, M. A long-tracked bogie design for forestry machines on soft and rough terrain. J. Terramech. 2013, 50, 73-83. [CrossRef]

29. Jamshidi, R.; Jaeger, D.; Raafatnia, N.; Tabari, M. Influence of two ground-based skidding systems on soil compaction under different slope and gradient conditions. Int. J. Eng. Sci. 2008, 19, 9-16.

30. Cambi, M.; Certini, G.; Neri, F.; Marchi, E. The impact of heavy traffic on forest soils: A review. For. Ecol. Manag. 2015, 338, 124-138. [CrossRef]

31. Cambi, M.; Certini, G.; Fabiano, F.; Foderi, C.; Laschi, A.; Picchio, R. Impact of wheeled and tracked tractors on soil physical properties in a mixed conifer stand. iForest 2016, 9, 89-94. [CrossRef]

32. Sánchez-Moreno, S.; Minoshima, H.; Ferris, H.; Jackson, L.E. Linking soil properties and nematode community composition: Effects of soil management on soil food webs. Nematology 2006, 8, 703-715. [CrossRef]

33. Baker, S.C.; Halpern, C.B.; Wardlaw, T.J.; Crawford, R.L.; Bigley, R.E.; Edgar, G.J.; Evans, S.A.; Franklin, J.F.; Jordan, G.J.; Karpievitch, Y.; et al. Short- and long-term benefits for forest biodiversity of retaining unlogged patches in harvested areas. For. Ecol. Manag. 2015, 353, 187-195. [CrossRef]

34. Arevalo, R.J.; Aboal, R.J. Species turnover during secondary succession in a laurel forest stand 50 years after clearcutting. For. Syst. 2015, 24, e007.

35. Powell, J.S.V.; Babbitt, K.J. Buffer-Mediated Effects of Clearcutting on In-Pool Amphibian Productivity: Can Aquatic Processes Compensate for Terrestrial Habitat Disturbance? Forests 2017, 8, 10. [CrossRef]

36. Guay-Picard, A.; Auty, D.; Munson, A.D.; Achim, A. Partial harvesting in boreal mixedwoods: A case for planned heterogeneity in industrial silvicultural prescriptions. For. Ecol. Manag. 2015, 358, 291-302. [CrossRef]

37. Drössler, L.; Fahlvik, N.; Wysocka, N.K.; Hjelm, K.; Kuehne, C. Natural Regeneration in a Multi-Layered Pinus sylvestris-Picea abies Forest after Target Diameter Harvest and Soil Scarification. Forests 2017, 8, 35. [CrossRef]

38. Puettmann, K.J.; Wilson, S.M.; Baker, S.C.; Donoso, P.J.; Drössler, L.; Amente, G.; Harvey, B.D.; Knoke, T.; Lu, Y.; Nocentini, S.; et al. Silvicultural alternatives to conventional even-aged forest management-What limits global adoption? For. Ecosyst. 2015, 2, 8. [CrossRef]

39. Maesano, M.; Picchio, R.; Lo Monaco, A.; Neri, F.; Lasserre, B.; Marchetti, M. Productivity and energy consumption in logging operation in a Cameroonian tropical forest. Ecol. Eng. 2013, 57, 149-153. [CrossRef]

40. Sist, P.; Nguyen-Thé, N. Logging damage and the subsequent dynamics of a dipterocarp forest in East Kalimantan (1990-1996). For. Ecol. Manag. 2002, 165, 85-103. [CrossRef]

41. Sist, P.; Sheil, D.; Kartawinata, K.; Priyadi, H. Reduced-impact logging in Indonesian Borneo: Some results confirming the need for new silvicultural prescriptions. For. Ecol. Manag. 2003, 179, 415-427. [CrossRef]

42. Tavankar, F.; Bonyad, A.E.; Majnounian, B. Affective factors on residual tree damage during selection cutting and cable-skidder logging in the Caspian forests, Northern Iran. Ecol. Eng. 2015, 83, 505-512. [CrossRef]

43. Parisi, V.; Menta, C.; Gardi, C.; Jacomini, C.; Mozzanica, E. Microarthropod communities as a tool to assess soil quality and biodiversity: A new approach in Italy. Agric. Ecosyst. Environ. 2005, 105, 323-333. [CrossRef]

44. Venanzi, R.; Picchio, R.; Piovesan, G. Silvicultural and logging impact on soil characteristics in Chestnut (Castanea sativa Mill.) Mediterranean coppice. Ecol. Eng. 2016, 92, 82-89. [CrossRef]

45. Rivas-Martínez, S. Global Bioclimatics. Clasificación Bioclimática de la Tierra. 2008. Available online: http:/ / www.globalbioclimatics.org/book/bioc/global_bioclimatics_2.htm (accessed on 15 February 2018). 
46. La Marca, O.; Mercurio, R.; Nocentini, L. Management and restoration on Italian afforestations under global change. Reforesta 2016, 2, 50-59. [CrossRef]

47. Hurlbert, S.H. Pseudorepliction and the design of ecological field experiments. Ecol. Monogr. 1984, 54, 187-211. [CrossRef]

48. Marchi, E.; Picchio, R.; Mederski, P.S.; Vusić, D.; Perugini, M.; Venanzi, R. Impact of silvicultural treatment and forest operation on soil and regeneration in Mediterranean Turkey oak (Quercus cerris L.) coppice with standards. Ecol. Eng. 2016, 95, 475-484. [CrossRef]

49. Picchio, R.; Maesano, M.; Savelli, S.; Marchi, E. Productivity and energy balance in conversion of a Quercus cerris L. coppice stand into high forest in Central Italy. Croat. J. For. Eng. 2009, 30, 15-26.

50. Braun-Blanquet, J. Plant Sociology-The Study of Plant Communities, 1st ed.; McGraw-Hill Book Company: London, UK, 1932; p. 472.

51. Pignatti, S. "Flora d'Italia"; Ed. Edagricole: Bologna, Italy, 1982.

52. Fiori, A. Nuova Flora Analitica d'Italia; Ed. ReInk Books: Firenze, Italy, 1923.

53. Castroviejo, S.; Aedo, C.; Cirujano, S.; Lainz, M.; Montserrat, P.; Morales, R.; Munozgarmendia, F.; Navarro, C.; Paiva, J.; Soriano, C. Flora Iberica; Real Jardìn Botanico, CSIC: Madrid, Spain, 2005.

54. Tutin, T.G.; Burges, N.A.; Charter, A.O.; Edmondson, J.R.; Heywood, V.M.; Moore, D.M.; Valentine, D.H.; Walters, S.M.; Webb, D.A. Flora Europaea, 2nd ed.; University Press: Cambridge, UK, 1993; Volume 1.

55. Tutin, T.G.; Heywood, V.M.; Burges, N.A.; Valentine, D.H.; Walters, S.M.; Webb, D.A. Flora Europaea; University Press: Cambridge, UK, 1969; Volume 2-5.

56. Tavankar, F.; Majnounian, B.; Bonyad, A.E. Felling and skidding damage to residual trees following selection cutting in Caspian forests of Iran. J. For. Sci. 2013, 59, 196-203. [CrossRef]

57. Pielou, E.C. The measurement of diversity in different types of biological collections. J. Theor. Biol. 1966, 13, 131-144. [CrossRef]

58. Burton, P.J.; Balisky, A.C.; Coward, L.P.; Cumming, S.G.; Kneeshaw, D.D. The value of managing for biodiversity. For. Chron. 1992, 68, 225-237. [CrossRef]

59. Begehold, H.; Rzanny, M.; Winter, S. Patch patterns of lowland beech forests in a gradient of management intensity. For. Ecol. Manag. 2016, 360, 69-79. [CrossRef]

60. Astolfi, S.; Zuchi, S.; De Cesare, F.; Badalucco, L.; Grego, S. Cadmium-induced changes in soil biochemical characteristics of oat (Avena sativa L.) rhizosphere during early growth stages. Soil Res. 2011, 49, 642-651. [CrossRef]

61. Moore, S.E.; Allen, H.L. Plantation Forestry. Maintaining Biodiversity in Forest Ecosystems; M.L. Hunter Cambridge University Press: New York, NY, USA, 1999; pp. 400-433.

62. Brosofske, K.D.; Chen, J.; Crow, T.R. Understory vegetation and site factors: Implications for a managed Wisconsin landscape. For. Ecol. Manag. 2001, 146, 75-87. [CrossRef]

63. Poorbabaei, H.; Poorrahmati, G. Plant species diversity in loblolly pine (Pinus taeda L.) and sugi (Cryptomeria japonica D. Don.) plantations in the western Guilan, Iran. Int. J. Biodvers. Conserv. 2009, 1, 38-44.

64. Carnevale, N.J.; Montagnini, F. Facilitating regeneration of secondary forests with the use of mixed and pure plantations of indigenous tree species. For. Ecol. Manag. 2002, 163, 217-227. [CrossRef]

65. Gratani, L.; Frattaroli, A.R.; Console, C. Regeneration of the undergrowth in reafforested areas with Pinus nigra, in the High Aterno Valley (Italy). Belg. J. Bot. 1994, 127, 61-66.

66. Lindgren, P.M.; Ransome, D.B.; Sullivan, D.S.; Sullivan, T.P. Plant community attributes 12 to 14 years following precommercial thinning in a young lodgepole pine forest. Can. J. For. Res. 2006, 36, 48-61. [CrossRef]

67. Cantiani, P.; De Meo, I.; Becagli, C.; Bianchetto, E.; Cazau, C.; Mocali, S.; Salerni, E. Effects of thinnings on plants and fungi biodiversity in a Pinus nigra plantation: A case study in central Italy. For. Ideas 2015, 21, 149-162.

68. Fredericksen, T.S.; Ross, B.D.; Hoffman, W.; Morrison, M.L.; Beyea, J.; Johnson, B.N.; Lester, M.B.; Ross, E. Short-term understory plant community response to timber harvesting intensity on non-industrial forestlands in Pennsylvania. For. Ecol. Manag. 1999, 116, 129-139. [CrossRef]

69. Thysell, D.R.; Carey, A.B. Effects of Forest Management on Understory and Overstory Vegetation: A Retrospective Study; USDA Forest Service General Technical Report PNW-GTR-488; U.S. Department of Agriculture: Portland, OR, USA, 2000. 
70. Lust, N.; Muys, B.; Nachtergale, L. Increase of biodiversity in homogeneous Scots pine stands by an ecologically diversified management. Biodivers. Conserv. 1998, 7, 249-260. [CrossRef]

71. Götmark, F.; Paletto, H.; Nordén, B.; Götmark, E. Evaluating partial cutting in broadleaved temperate forest under strong experimental control: Short-term effects on herbaceous plants. For. Ecol. Manag. 2005, 214, 124-141. [CrossRef]

72. Cambi, M.; Hoshika, Y.; Mariotti, B.; Paoletti, E.; Picchio, R.; Venanzi, R.; Marchi, E. Compaction by a forest machine affects soil quality and Quercus robur L. seedling performance in an experimental field. For. Ecol. Manag. 2017, 384, 406-414. [CrossRef]

73. Fekete, I.; Varga, C.; Biró, B.; Tóth, J.A.; Várbíró, G.; Lajtha, K.; Szabó, G.; Kotroczó, Z. The effects of litter production and litter depth on soil microclimate in a central European deciduous forest. Plant Soil 2016, 398, 291-300. [CrossRef]

74. Blasi, S.; Menta, C.; Balducci, L.; Delia Conti, F.; Petrini, E.; Piovesan, G. Soil microarthropod communities from Mediterranean forest ecosystems in Central Italy under different disturbances. Environ. Monit. Assess. 2013, 185, 1637-1655. [CrossRef] [PubMed]

75. Marchi, E.; Picchio, R.; Spinelli, R.; Verani, S.; Venanzi, R.; Certini, G. Environmental impact assessment of different logging methods in pine forests thinning. Ecol. Eng. 2014, 70, 429-436. [CrossRef]

(C) 2018 by the authors. Licensee MDPI, Basel, Switzerland. This article is an open access article distributed under the terms and conditions of the Creative Commons Attribution (CC BY) license (http://creativecommons.org/licenses/by/4.0/). 